\title{
Baseline characteristics of climate, permafrost and land cover from a new permafrost observatory in the Lena River Delta, Siberia (1998-2011)
}

\author{
J. Boike ${ }^{1}$, B. Kattenstroth ${ }^{1}$, K. Abramova ${ }^{2}$, N. Bornemann ${ }^{1}$, A. Chetverova ${ }^{3,4}$, I. Fedorova ${ }^{3,4}$, K. Fröb ${ }^{1}$, M. Grigoriev ${ }^{5}$, \\ M. Grüber ${ }^{1}$, L. Kutzbach ${ }^{6}$, M. Langer ${ }^{1}$, M. Minke ${ }^{7}$, S. Muster ${ }^{1}$, K. Piel ${ }^{1}$, E.-M. Pfeiffer ${ }^{6}$, G. Stoof ${ }^{1}$, S. Westermann ${ }^{8}$, \\ K. Wischnewski ${ }^{1}$, C. Wille ${ }^{6}$, and H.-W. Hubberten ${ }^{1}$ \\ ${ }^{1}$ Alfred Wegener Institute for Polar and Marine Research, Telegrafenberg A43, 14473 Potsdam, Germany \\ ${ }^{2}$ Lena Delta Nature Reserve, Tiksi, 678400, Yakutia, Russia \\ ${ }^{3}$ Arctic and Antarctic Research Institute, 38, Beringa str., St. Petersburg, 199397, Russia \\ ${ }^{4}$ Saint Petersburg State University, 33-35, 10 line, V.O., St. Petersburg, 199178, Russia \\ ${ }^{5}$ Melnikov Permafrost Institute, Siberian Branch, Russian Academy of Sciences, Yakutsk, Russia \\ ${ }^{6}$ University of Hamburg, KlimaCampus, Institute of Soil Science, Hamburg, Germany \\ ${ }^{7}$ Institute of Botany and Landscape Ecology, Ernst-Moritz-Arndt University, Greifswald, Germany \\ ${ }^{8}$ Department of Geosciences, University of Oslo, Oslo, Norway \\ Correspondence to: J. Boike (julia.boike@ awi.de)
}

Received: 4 September 2012 - Published in Biogeosciences Discuss.: 8 October 2012

Revised: 25 February 2013 - Accepted: 26 February 2013 - Published: 27 March 2013

\begin{abstract}
Samoylov Island is centrally located within the Lena River Delta at $72^{\circ} \mathrm{N}, 126^{\circ} \mathrm{E}$ and lies within the Siberian zone of continuous permafrost. The landscape on Samoylov Island consists mainly of late Holocene river terraces with polygonal tundra, ponds and lakes, and an active floodplain. The island has been the focus of numerous multidisciplinary studies since 1993, which have focused on climate, land cover, ecology, hydrology, permafrost and limnology. This paper aims to provide a framework for future studies by describing the characteristics of the island's meteorological parameters (temperature, radiation and snow cover), soil temperature, and soil moisture. The land surface characteristics have been described using high resolution aerial images in combination with data from ground-based observations. Of note is that deeper permafrost temperatures have increased between 0.3 to $1.3^{\circ} \mathrm{C}$ over the last five years. However, no clear warming of air and active layer temperatures is detected since 1998, though winter air temperatures during recent years have not been as cold as in earlier years.
\end{abstract}

Data related to this article are archived under: http://doi.pangaea.de/10.1594/PANGAEA.806233.

\section{Introduction}

Arctic regions present a number of unique features whose influences on ecological processes remain inadequately understood. These features include continuously frozen ground (permafrost), extensive wetlands with shallow lakes and ponds, large seasonal variations in solar input and a short growing season. Over the last century the average surface temperature in the Arctic has increased by about $0.09^{\circ} \mathrm{C}$ per decade, a rate $50 \%$ greater than that observed over the Northern Hemisphere as a whole (ACIA, 2005; AMAP, 2011).

Arctic soils and peatlands act as large carbon stores, but our understanding of feedback mechanisms provoked by rising temperatures and their effects on trace gases remains limited. One current hypothesis is that a warming climate will result in hydrologic intensification, based on the assumption that a warmer atmosphere will retain more water, resulting in higher precipitation and increased runoff in rivers (Rawlins et al., 2009a).

The thickness and areal distribution of permafrost are directly affected by snow and vegetation cover, topography, bodies of water, the geothermal heat flux and the air temperature. Predicting the sensitivity of permafrost to a warming climate is complicated by the complex interactions between 


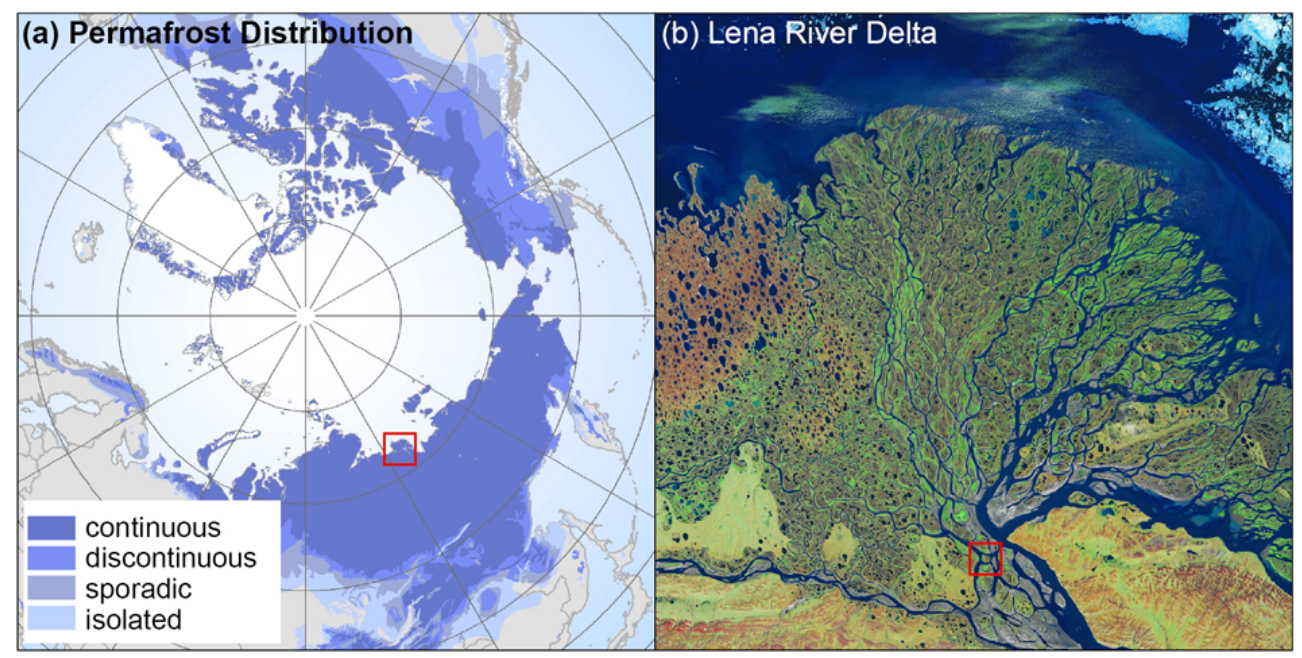

Fig. 1. (a) Circumpolar permafrost distribution (Brown et al., 1998) and the Lena River Delta. (b) Location of the Samoylov study site within the Lena River Delta, Eastern Siberia (NASA, 2000).

the hydrology, the thermal regimes of the soil and the vegetation, which can lead to both positive and negative feedbacks on permafrost. Shrub cover has been observed to reduce the mean annual permafrost temperature by several degrees (Blok et al., 2010). This effect can be offset by an increase in snow cover associated with increased shrub cover (Sturm et al., 2001) that insulates the permafrost from cold winter temperatures (Blok et al., 2010). Overall changes in land cover, such as in the vegetation type and distribution or the areal extent of water bodies and drainage systems, will affect the vertical and horizontal fluxes of water, energy and matter. Wetlands, ponds and lakes are typical features of northern ecosystems and play an important role in both local and regional climate and hydrology by regulating heat and water fluxes, as well as affecting the carbon cycle.

The area of investigation was on Samoylov Island, in the Lena River Delta of Northern Siberia. The objective of this study was to outline the characteristics of this area over a period from 1998 to 2011, with respect to its climate, permafrost, active layer, land cover and hydrology, using measurements recorded on site. The intention is to provide a framework for current and future field studies and experimental research, aiming to monitor and predict future changes. Research in this area has been in progress since 1993, but initially only as a part of on-going Arctic research networks. A large new research station offering a variety of facilities for the continuation of existing research projects, as well as for new research projects, is currently being established by the Russian Academy of Sciences. This site will, thus, serve as a new Arctic observatory in an area that is representative of the of the low-lying wetlands of Northern Siberia, as well as of deltaic processes in the Arctic.

\section{Site description and data collection facilities at the new Samoylov observatory}

The Lena River Delta in Northern Yakutia is the largest delta in the Arctic and its catchment area $\left(2430000 \mathrm{~km}^{2}\right)$ is one of the largest in the whole of Eurasia (Costard and Gautier, 2007). The Lena River distributes water and sediment in the four main channels (Olenekskaya, Tumatskaya, Bykovskaya, Trofimovskaya) before discharging in total about $30 \mathrm{~km}^{3}$ of water through the delta into the Arctic Ocean every year (Fedorova et al., 2012), and its discharge has been observed to be increasing (Rawlins et al., 2009b).

Three main geomorphological units (river terraces) in the Lena River Delta were identified by Grigoriev (1993). The first terrace and is characterised by ice-wedge polygonal tundra, large thermokarst lakes and active flood plains. This terrace formed during the Holocene and occupies most of the central and eastern parts of the delta. The second terrace is characterised by sandy sediments with a low ice content and many large thermokarst lakes, and occurs in the northwestern part of the delta; it was formed between the Late Pleistocene and early Holocene. The third and oldest terrace is an erosional remnant of a Late Pleistocene plain consisting of fine-grained, organic-rich and ice-rich sediments, characterised by polygonal ground and thermokarst processes. The study area, Samoylov Island, is located on the first terrace. The island is one of the 1500 islands that make up the Lena River Delta (Fig. 1) and is located within one of the main river channels, in the southern part of the delta $\left(72^{\circ} 22^{\prime} \mathrm{N}, 126^{\circ} 28^{\prime} \mathrm{E}\right)$. Continuous permafrost underlies the area to between about 400 and $600 \mathrm{~m}$ below surface (Yershov et al., 1991). The main features of the annual energy balance are low net radiation, higher atmospheric latent heat flux than sensible heat flux, and a large proportion of soil heat flux (Boike et al., 2008; Kutzbach, 2006; Langer et al., 


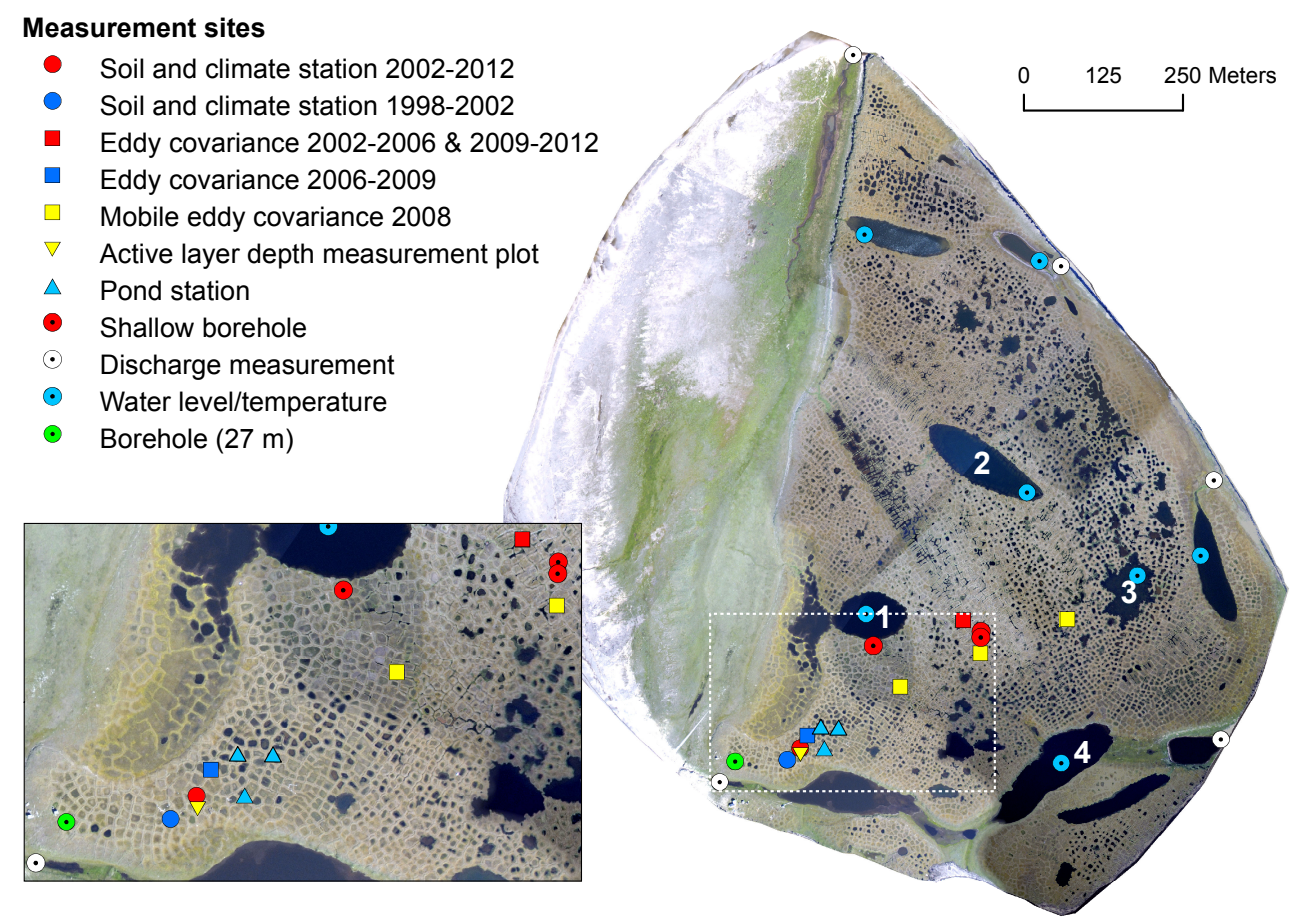

Fig. 2. Measurement sites on Samoylov Island since 1998. Long-term water level/temperature measurement stations have been installed in the four thermokarst lakes since 2009.

2011a, b). Previous research has focused on energy and carbon cycling (Abnizova et al., 2012; Knoblauch et al., 2008; Kutzbach et al., 2004, 2007; Liebner et al., 2011; Runkle et al., 2013; Sachs et al., 2008, 2010; Wille et al., 2008), ecosystem C modelling (Zhang et al., 2012), land cover classification (Muster et al., 2012; Schneider et al., 2009), spatial heterogeneity and upscaling of land surface temperature (Langer et al., 2010), biological and paleoenvironmental reconstruction (Wetterich et al., 2008), and the characteristics of microbial communities (Wagner et al., 2007).

A photo-mosaic of Samoylov Island showing the locations of observation instruments is presented in Fig. 2. The climate data record (air temperature, radiation, humidity, wind speed and direction, and snow depth) is derived from a weather station installed in 1998 (Boike et al., 2008). This station is currently the only automated weather station operating in the Lena River Delta. Gaps in the data from this station have, whenever possible, been filled with data from temporary climate and eddy covariance stations located in close proximity of the weather station (Langer et al., 2011a, b).

The closest weather station where data are collected as part of the Regional Basic Synoptic Network (World Meteorological Organisation: www.wmo.in) is Tiksi, about $110 \mathrm{~km}$ east from Samoylov, located on the continent. While air temperatures are similar compared to Samoylov, the precipitation shows distinct differences due to its proximity to the Laptev Sea and a location that is surrounded by mountains.
The spatial distribution of snow cover was recorded with an automated camera and the snow depth recorded from measurements in the field. Manual data collection has included vegetation, snow and soil surveys, as well as sampling, geomorphological mapping and aerial photography using balloons or blimps (Scheritz et al., 2008; Muster et al., 2012, 2013). Active layer thickness has been measured since 2002 on a 150 point grid, using a steel rod pushed vertically into the soil to the depth at which ice-bonded soil provides firm resistance (CALM Active Layer Protocol: http://www.udel. edu/Geography/calm/research/active_layer.html).

A deep borehole was drilled into the permafrost during the spring of 2006 and a temperature sensor chain installed in August 2006, with 23 temperature sensors down to a depth of $26.75 \mathrm{~m}$ (Fig. 2). The temperature sensor chain was inserted into a close-fitting PVC tube to allow reinstallation and recalibration of sensors. The absolute accuracy of the temperature sensors is $\pm 0.005^{\circ} \mathrm{C}$ across the range from $-40{ }^{\circ} \mathrm{C}$ to $35^{\circ} \mathrm{C}$ (RBR Ltd.). A second $5 \mathrm{~cm}$ (outside diameter) PVC tube was inserted into the borehole to permit additional (geophysical) measurements to be made in the future. The remaining air space in the borehole was backfilled with dry sand.

An automated weather station (Campbell Scientific) measuring air temperature and net radiation was installed in 2006 within a $90 \mathrm{~cm}$ deep polygonal pond, together with PT100 temperature sensors in the water and in the sediment.

In July 2009, water level and temperature sensors (HOBO Temp Pro v2, HOBO U20, Onset, $\pm 0.2^{\circ} \mathrm{C}$ across 
Table 1. Land cover spatial statistics for the mapped area of polygonal tundra on Samoylov Island. Ratio (\%) is the percentage of the total mapped area of polygonal tundra.

\begin{tabular}{|c|c|c|c|c|c|}
\hline Land cover & $\begin{array}{r}\text { Total surface area } \\
\left(\mathrm{km}^{2}\right)\end{array}$ & $\begin{array}{r}\text { Ratio } \\
(\%)\end{array}$ & $\begin{array}{r}\text { Density } \\
\left(\text { per } \mathrm{km}^{2}\right)\end{array}$ & $\begin{array}{r}\text { Mean patch size } \\
\qquad\left(\mathrm{m}^{2}\right)\end{array}$ & $\begin{array}{r}\text { St.dev. (patch size) } \\
\left(\mathrm{m}^{2}\right)\end{array}$ \\
\hline First terrace-polygonal tundra & 2.85 & & & & \\
\hline Open water bodies ${ }^{\mathrm{a}}$ & 0.46 & 15 & 625 & 258 & 2242 \\
\hline Polygonal ponds $<0.1$ ha (including frost cracks) & 0.16 & & 578 & 54 & 40 \\
\hline Polygonal lakes $0.1-1$ ha & 0.07 & & 44 & 819 & 1136 \\
\hline Thermokarst lakes $>1$ ha & 0.22 & & 4 & 26884 & 12628 \\
\hline Overgrown water ${ }^{\mathrm{b}}$ & 0.17 & 10 & 1062 & 58 & 379 \\
\hline Wet tundra ${ }^{b}$ & 0.29 & 17 & 2164 & 47 & 360 \\
\hline Dry tundra ${ }^{b}$ & 1.00 & 58 & - & - & - \\
\hline Flood plain ${ }^{\mathrm{a}}$ & 1.49 & & & & \\
\hline Dwarf shrub dominated tundra & 0.84 & 56 & - & - & - \\
\hline Mainly non-vegetated area & 0.65 & 44 & - & - & - \\
\hline
\end{tabular}

a Derived from classification of visible (VIS) aerial imagery (summer 2007), covering the whole of the terrace.

b Derived from classification of visible and near infrared (VNIR) aerial imagery (summer 2008), covering a subset of the terrace (Muster et al., 2012).

a temp. range of $0{ }^{\circ} \mathrm{C}$ to $70^{\circ} \mathrm{C}$, and $\pm 0.4{ }^{\circ} \mathrm{C}$ across a temp. range of $-40^{\circ} \mathrm{C}$ to $0^{\circ} \mathrm{C}$ ) were installed within the water columns of several of the thermokarst lakes on Samoylov Island. Temperature sensors were placed directly above the sediment-water interface and then at $2 \mathrm{~m}$ intervals up to $2 \mathrm{~m}$ below water surface (Fig. 2 ). The sensors were attached to a weighted rope suspended from buoys about $2 \mathrm{~m}$ below the water surface. Bathymetric surveys were carried out in the thermokarst lakes in 2008, using an echo sounder and GPS.

\section{Biosphere surface characteristics (vegetation and soil)}

\subsection{Land cover spatial statistics}

Samoylov Island consists of a flood plain in the west and an elevated river terrace in the east that is characterised by polygonal tundra. The polygonal tundra on Samoylov Island forms a highly fragmented land cover pattern consisting of dry polygonal ridges with wet depressed centres, as well as numerous larger water bodies (Fig. 3 and Table 1; Muster et al., 2012). We distinguish locally between "wet" and "dry" tundra on the basis of differences in surface wetness (Muster et al., 2012). "Dry" tundra conforms to the moist-herbaceous plant communities identified on the Circumpolar Arctic Vegetation Map (CAVM Team, 2003) and occurs on polygon ridges, well drained plateaus and elevated polygon centres, while "wet" tundra is found in depressed polygon centres, in water channels and on collapsed ridges.

The patterned terrain consists predominantly of ice-wedge polygonal networks with depressed centers and thermokarst lakes (Fig. 3). The polygonal surface structure is due to the formation of ice-wedges below the soil's surface. Because of the extreme cold in winter months the frozen soil undergoes thermal contraction and, if the horizontal tension becomes too great, develops vertical cracks in a more or less regu- lar pentagonal, hexagonal, or orthogonal network (Lachenbruch, 1962, 1966). These cracks broaden out to widths of several millimeters and range in depth from a few decimetres to several metres. Sublimating water vapour or infiltrating meltwater and rainwater can lead to ice formation within the permafrost soil. During summer warming the frozen soil body tends to expand again, but the ice-wedges prevent horizontal expansion, resulting in compression and plastic deformation (Mackay, 2000). The soil then bulges up next to the ice-wedges and the edges of the polygon are, thus, built up to form elevated rims. Cracks may again develop during subsequent winters in the vicinity of the original cracks (the weakest points), if conditions are favourable. Thus, tapered ice bodies several metres wide can grow over time beneath the frost-cracks, leading to the formation of polygonal networks (Mackay, 2000).

Water surfaces are classified as either overgrown water, or open water with no vegetation. Overgrown water is found in troughs above ice-wedges, in polygon centres, and in the shallow parts of ponds and lakes. Water bodies are dominated numerically by the polygonal ponds, but dominated in area by the relatively few thermokarst lakes. The thermokarst process involves the thawing of ice-rich permafrost and subsidence of the ground surface. Thermokarst ponds are formed through water accumulating in the resulting depressions that potentially grow into larger thermokarst lakes (Jorgenson and Shur, 2007). Polygonal ponds (defined here as water bodies smaller than 0.1 ha, including frost cracks) with a surface area between 0.003 and 0.1 ha are abundant in the ice-wedge polygonal tundra on Samoylov Island. Polygonal ponds contribute $35 \%$ to the total water surface area. On average, there are 748 polygonal ponds per square kilometre in the study area (Table 1). Thermokarst lakes (defined here as larger than 1 ha) contribute about $49 \%$ to the total water surface area. The polygonal lakes (0.1-1 ha), including frost cracks, contributes only about $15 \%$ to the total mapped water surface 


\section{Land cover class}

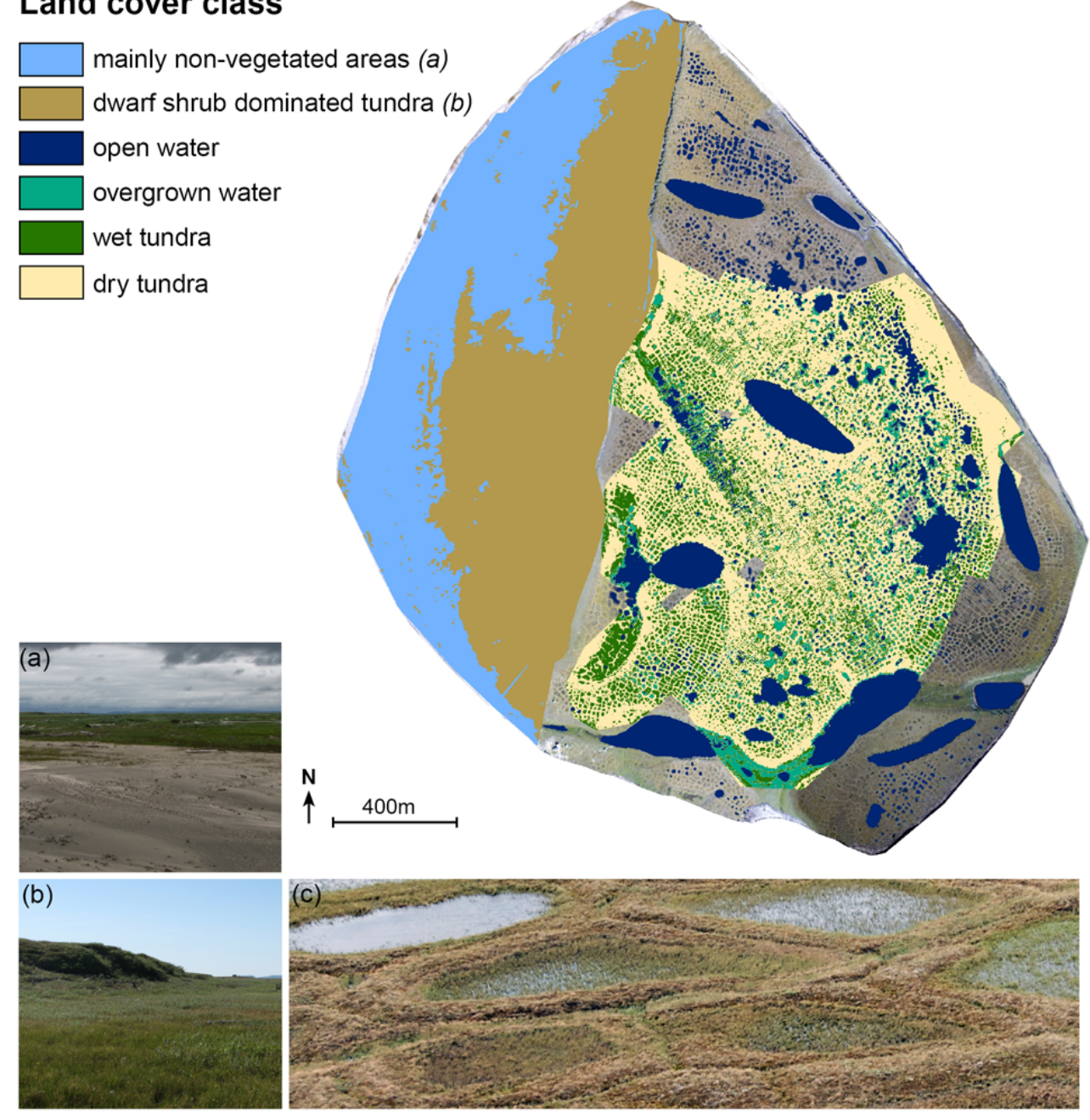

Fig. 3. Land cover classes on Samoylov Island. Classification of the eastern part of the island is based on Muster et al. (2012). The western part, which is non-vegetated or dwarf shrub tundra, is subject to flooding by the Lena River during spring. Overgrown water and wet and dry tundra were only classified for a subset of the terrace. The classification is overlain on the 2007 VIS orthophoto (grey colour).

area and form less than $1 \%$ of the total number of water bodies; they represent a transitional state between ponds and thermokarst lakes.

\subsection{Vegetation}

Between ten and twenty sampling points were selected for each of the ten land cover classes on Samoylov Island, based on the land cover map of the Lena River Delta (Schneider et al., 2009), and located on the ground by GPS. The vegetation was mapped in June 2006 into coverage classes (after Braun-Blanquet, 1964), on homogenous relevés of 25 to $100 \mathrm{~m}^{2}$. The nomenclature used follows Cherepanov (1995) for vascular plants, Abramov and Volkova (1998) for mosses, Frahm and Frey (1992) for liverwort, and Wirth (1995) for lichens. Non-hierarchical clustering of the relevés according to species cover was used to derive vegetation types, using the "K-means2" K-means partitioning programme of Legendre (2001) and including the Hellinger transformation (Legendre and Gallagher, 2001). This resulted in four main vegetation types: three on the first terrace and one on the flood plain (Table 2).

Large parts of the flood plain are devoid of vegetation. The overgrown parts of the flood plain are characterised by the Salix-Equisetum-Alopecurus alpinus community, dominated by willow shrubs (Salix glauca, S. lanata and S. reptans), horsetail (Equisetum), Poaceae (Alopecurus alpinus, Festuca rubra, Deschampsia borealis) and Tanacetum bipinnatum. While mosses are very rare on the floodplain, they form areas of dense cover on the first terrace.

The dry tundra is dominated by the moss species $\mathrm{Hy}$ locomium splendens, together with Dryas punctata, Polygonum viviparum, Astragalus frigidus, with willow shrubs (Salix glauca, S. lanata and S. reptans, S. reticulata), and 
Table 2. Dominant vegetation communities and key species on Samoylov Island by presence of key species in corresponding vegetation community (\%) and proportion of corresponding vegetation community covered by key species (\%).

\begin{tabular}{|c|c|c|c|c|}
\hline Habitat & Vegetation community & Key species & Presence $(\%)$ & Cover $(\%)$ \\
\hline Wet tundra & Drepanocladus revolvens & Drepanocladus revolvens & 81 & 40.4 \\
\hline Wet polygon centres & Meesia triquetra-Carex & Meesia triquetra & 78 & 8.5 \\
\hline and trenches & chordorrhiza community & Rhizomnium punctatum & 65 & 6.9 \\
\hline \multirow{4}{*}{ or collapsed ridges } & & Calliergon giganteum & 57 & 4.4 \\
\hline & & Carex chordorrhiza & 46 & 4.3 \\
\hline & & Comarum palustre & 49 & 1.2 \\
\hline & & Pedicularis sudetica & 60 & 0.4 \\
\hline Dry tundra & Hylocomium splendens - & Hylocomium splendens & 100 & 68 \\
\hline Well-drained & Dryas punctata & Dryas punctata & 98 & 2.9 \\
\hline plateaus, polygon & community & Peltigera & 94 & 1.1 \\
\hline ridges, and elevated & & Polygonum viviparum & 86 & 0.5 \\
\hline \multirow[t]{6}{*}{ polygon centres } & & Saxifraga punctata & 78 & 0.4 \\
\hline & & Astragalus frigidus & 77 & 0.6 \\
\hline & & Luzula tundricola & 66 & 0.4 \\
\hline & & Lagotis glauca & 66 & 0.3 \\
\hline & & Saxifraga hirculus & 60 & 0.3 \\
\hline & & Valeriana capitata & 64 & 0.3 \\
\hline \multirow[t]{5}{*}{ Flood plain } & Equisetum - Salix - & Salix glauca/reptans/lanata & 81 & 13.7 \\
\hline & Alopecurus alpinus & Equisetum $\mathrm{sp}$ & 78 & 7.0 \\
\hline & community & Alopecurus alpinus & 51 & 0.3 \\
\hline & & Festuca rubra & 32 & 1.3 \\
\hline & & Deschampsia borealis & 32 & 0.8 \\
\hline Overgrown water & Arctophila fulva reeds & Arctophila fulva & 100 & 24.8 \\
\hline
\end{tabular}

lichens (Peltigera) belonging to the Hylocomium splendensDryas punctata-lichen community.

The vegetation of the wet tundra is made up of the Drepanocladus revolvens-Meesia triquetra-Carex chordorrhiza community (i.e., the hydrophilic mosses Drepanocladus revolvens, Meesia triquetra, and Calliergon giganteum), the sedge Carex chordorrhiza, marsh cinquefoil (Comarum palustre), sudetic lousewort (Pedicularis sudetica), and others.

Carex concolor, together with the moss species Tomentypnum nitens, Aulacomnium palustre, and Aulacomnium turgidum, are very common in both the Drepanocladus revolvens-Meesia triquetra-Carex chordorrhiza community of the wet tundra and the Hylocomium splendens-Dryas punctata-lichen community of the dry tundra. While Carex concolor is very tolerant with respect to water supply and has a high presence both in wet polygon depressions $(97 \%)$ and on dry polygon ridges $(90 \%)$, with coverage levels of $12 \%$ and $4.4 \%$, respectively, the previously mentioned moss species (Tomentypnum nitens, Aulacomnium palustre, and Aulacomnium turgidum) prefer intermediate moisture conditions such as those found on hummocks in depressed polygon centres, or on the lower parts of ridge slopes. Minke et al. (2009) classified this intermediate zone as a separate vegetation community on the basis of micro-scale mapping of low-centred polygons, but such differentiation would require much smaller relevés of about $1 \mathrm{~m}^{2}$.
The fourth vegetation community on Samoylov consists almost entirely of Arctophila fulva, growing in water in the shallow parts of the lakes.

\subsection{Permafrost-affected soils}

Most of the land surface area of Samoylov Island is characterised by permafrost within $1 \mathrm{~m}$ depth from the mineral soil surface and most soils are, therefore, classified as Gelisols according to the US Soil Taxonomy (Soil Survey Staff, 2010). However, Entisols (more specifically Typic Gelaquents) that have neither permafrost nor gelic materials within $1 \mathrm{~m}$ depth from the soil surface, can also be found on the unvegetated banks of the Lena River. The soils on the lateHolocene river terrace in the eastern part of the island and the modern floodplain in the western part of the island have been affected by sustained fluvial and/or aeolian sedimentation processes, which have led to a stratified soil structure that consists of alternating layers of sands and silts, with varying contents of autochthonous and heterochthonous organic matter. Fluvial sedimentation is, of course, currently much more pronounced on the modern floodplain, while aeolian sedimentation occurs on both geomorphological units. The grain size distribution of the sediments is dominated by sand and silt particle sizes, and the gravimetric clay content is typically below $15 \%$ except in backswamp sedimentation situations. 


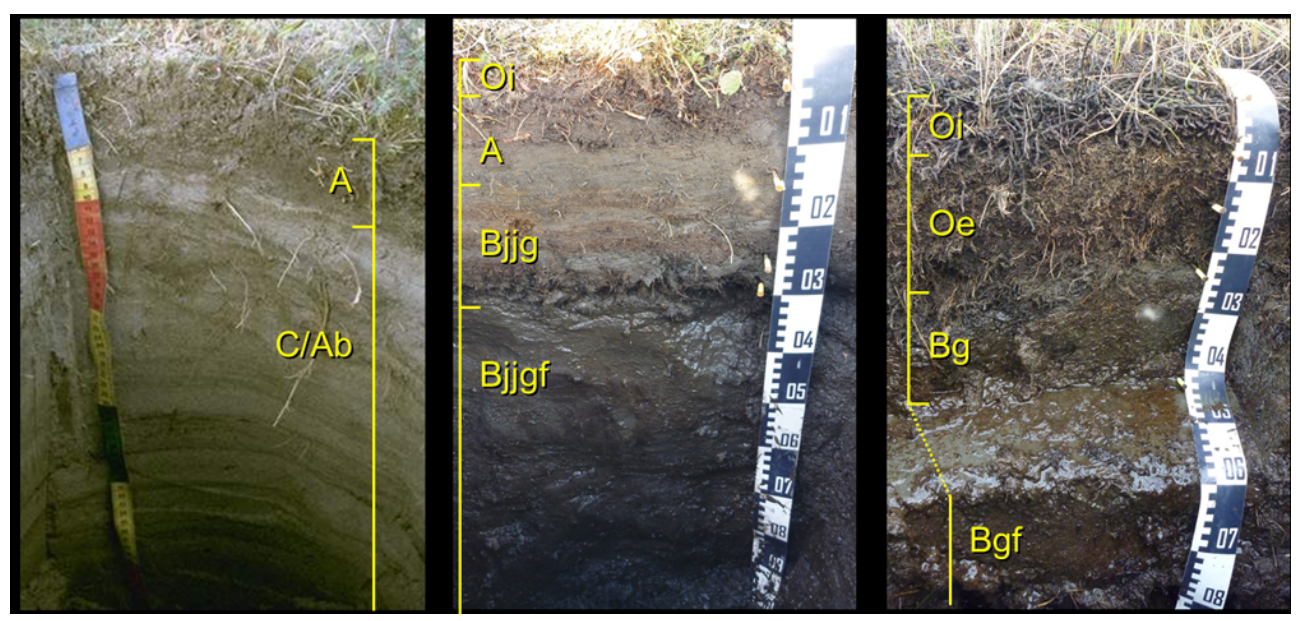

Fig. 4. Photos of three typical soils at Samolyov Island. (a) Typic Psammorthel, floodplain, natural levee, 2001; (b) Typic Aquiturbel, first terrace, polygon rim, 2012; (c) Typic Historthel, first terrace, polygon centre, 2012. Typical soil properties of such soils are given in Table 3.

The floodplain is characterised by a variety of noncryoturbated permafrost-affected soils (Orthels) that differ in soil texture, water saturation and the amount of accumulated organic matter, depending on their situation within the floodplain relief. Typic Psammorthels, which are Orthels with high sand contents, low organic matter contents and low water tables, are found on natural levees formed by high-flood fluvial processes and have a covering of wind-blown sand (Sanders et al., 2010). Orthels with finer textures, higher water tables and different degrees of organic matter accumulation, such as Typic Aquorthels and Ruptic-Histic Aquorthels, are found in lower-lying areas behind the levees.

The late-Holocene river terrace in the eastern part of Samoylov Island is, to a major extent, characterised by Glacic Aquiturbels, Typic Aquiturbels and Typic Historthels soils. The properties of this soil complex, which is very typical of polygonal tundra, have been described in detail by Becker et al. (1999), Fiedler et al. (2004), Kutzbach et al. (2004), Kutzbach (2006), Sanders et al. (2010) and Zubrzycki et al. (2012a). The Glacic Aquiturbels occur above the ice-wedges that develop below the elevated polygon rims. Typic Aquiturbels occur at elevated polygon rims, but do not show a pure ice-layer within $1 \mathrm{~m}$ from the soil surface. They are cryoturbated, mainly due to the on-going ice-wedge polygon morphodynamics. These soils are characterised by oxidative conditions in the top $15-20 \mathrm{~cm}$, and by high water contents and reductive conditions below. There is substantial peat accumulation on the slopes of the elevated polygon rims, but only a minor amount on the top of the rims. The Typic Historthels are located in the depressed polygon centres and are characterised by water tables that fluctuate around the soil surface (roughly between $10 \mathrm{~cm}$ below and above the soil surface), soil conditions that are already reductive in the uppermost soil horizons, and substantial peat accumulation. In some areas the relief of the low-centre polygons is inverted due to erosion and thawing of the icewedges, forming high-centre polygons that are characterised by a soil complex of Typic Aquiturbels (on the edges of elevated polygon centres) and Typic Aquorthels (on the elevated polygon centres). These soils still show redoximorphic features below $15-20 \mathrm{~cm}$, but water levels are too low for active peat accumulation. Typic Psammorthels and sand-rich Typic Aquorthels can also be found in areas of enhanced aeolian sand sedimentation near the scarps of the late-Holocene terrace (Sanders et al., 2010).

Typical soil profiles and selected properties of the active layer components of the dominant soil types on Samoylov Island are compiled in Table 3, from previously published work. Photos of some typical soil profiles found on Samoylov Island are shown in Fig. 4. New detailed information on the bulk density, ice content, carbon content and nitrogen content of the active-layer, and also of the upper part of the permanently frozen ground (from 29 soil cores from Samoylov Island), is presented in Zubrzycki et al. (2012b). The characteristics of the deeper sediments of the first terrace have been obtained from a $4 \mathrm{~m}$ soil core obtained from a polygonal rim site close to lake 1; Fig. 2 "shallow borehole"), revealing no major variations with depth in the density, ice content, porosity, or grain size fractions (Fig. 5). The soil is mostly composed of 37 to $76 \%$ silt and 18 to $60 \%$ sand, and exhibits a high porosity and ice content (up to $80 \%$ ).

The composition of the soil determines its thermo-physical characteristics such as its heat capacity $\left(C_{\mathrm{h}}\right)$ and thermal conductivity $\left(K_{\mathrm{h}}\right)$, which can vary markedly between frozen and unfrozen conditions. The heat capacity was calculated from the mineral, organic and ice contents of the soil core, while the thermal conductivity was inferred from numerical heat transfer modelling and soil temperature records. Detailed 
Table 3. Typical soil profile structures and selected properties of the dominant soil types on Samoylov Island.

\begin{tabular}{|c|c|c|c|c|c|c|c|c|c|}
\hline $\begin{array}{l}\text { Geomorphological } \\
\text { situation }\end{array}$ & Soil type ${ }^{\mathrm{a}}$ & Horizon $^{\mathrm{a}}$ & Thickness $(\mathrm{cm})$ & Texture $^{\mathrm{a}, \mathrm{b}}$ & $\begin{array}{l}\text { Bulk density }{ }^{\mathrm{b}} \\
\left(\mathrm{g} \mathrm{cm}^{-3}\right)\end{array}$ & $\begin{array}{l}\text { Porosity } \\
\left(\mathrm{m} \mathrm{m}^{-3}\right)\end{array}$ & $\begin{array}{l}\text { Organic } \text { carbon }^{\mathrm{c}} \\
\left(\mathrm{g} \mathrm{g}^{-1}\right)\end{array}$ & $\mathrm{pH}^{\mathrm{d}, \mathrm{c}}$ & Reduc. cond. ${ }^{\mathrm{e}}$ \\
\hline \multirow{4}{*}{$\begin{array}{l}\text { First terrace, } \\
\text { polygon centre } \\
\text { ("wet tundra") }\end{array}$} & Typic & $\mathrm{Oi}$ & $11 \ldots 15$ & peat+sand & $0.1 \ldots 0.4$ & $0.95 \ldots 0.99$ & $0.16 \ldots 0.22$ & $4.7 \ldots 5.0$ & no \\
\hline & \multirow[t]{3}{*}{ Historthels } & OeBg & $13 \ldots 19$ & peat + sand & $0.1 \ldots 0.9$ & $0.8 \ldots 0.97$ & $0.05 \ldots 0.14$ & $4.5 \ldots 5.0$ & yes \\
\hline & & $\mathrm{Bg}$ & $0 \ldots 5$ & sand... loam & $0.6 \ldots 1.0$ & 0.7 & 0.02 & $4.5 \ldots 5.1$ & yes \\
\hline & & $\mathrm{Bgf}$ & n.d. & sand... loam & $0.7 \ldots 1.1$ & n.d. & $0.04 \ldots 0.05$ & $5.1 \ldots 5.5$ & yes \\
\hline \multirow{5}{*}{$\begin{array}{l}\text { First terrace, } \\
\text { polygon rim } \\
\text { ("dry tundra") }\end{array}$} & Glacic and Typic & Oi & $0 \ldots 10$ & peat+sand & $0.1 \ldots 0.4$ & $0.95 \ldots 0.99$ & 0.17 & 4.9 & no \\
\hline & \multirow[t]{4}{*}{ Aquiturbels } & $\mathrm{Ajj}$ & $10 \ldots 15$ & sand... loam & $0.9 \ldots 1.35$ & $0.5 \ldots 0.7$ & $0.02 \ldots 0.03$ & $5.6 \ldots 6.3$ & no \\
\hline & & Bjjg & $25 \ldots 35$ & sand... loam & $1.0 \ldots 1.35$ & $0.5 \ldots 0.7$ & $0.02 \ldots 0.06$ & $4.9 \ldots 6.2$ & yes \\
\hline & & Bjjgf & $15 \ldots 25$ & sand... loam & n.d. & n.d. & $0.01 \ldots 0.03$ & $5.4 \ldots 6.0$ & yes \\
\hline & & (Wf) & n.d. & ice & n.d. & $\sim 1$ & n.d. & n.d. & n.d. \\
\hline \multirow{3}{*}{$\begin{array}{l}\text { Floodplain, } \\
\text { natural levee }\end{array}$} & Typic & A & $7 \ldots 11$ & loamy sand & $1.2 \ldots 1.4$ & 0.6 & $0.01 \ldots 0.03$ & $6.6 \ldots 6.7$ & no \\
\hline & \multirow[t]{2}{*}{ Psammorthels } & $\mathrm{C} / \mathrm{Ab}$ & $80 \ldots 87$ & sand/loam & $1.2 \ldots 1.4$ & 0.6 & $0.001 / 0.02$ & $6.2 \ldots 6.7$ & no \\
\hline & & $\mathrm{Cf}$ & n.d. & n.d. & n.d. & n.d. & n.d. & n.d. & no \\
\hline \multirow{4}{*}{$\begin{array}{l}\text { Floodplain, } \\
\text { behind levee }\end{array}$} & Typic & A & 9 & loam & n.d. & n.d. & 0.03 & 6.7 & no \\
\hline & \multirow{3}{*}{$\begin{array}{l}\text { Aquorthels, } \\
\text { sandy }\end{array}$} & $\mathrm{C} / \mathrm{Ab}$ & 22 & sand/loamy sand & n.d. & n.d. & $0.0004 / 0.03$ & 6.4 & no \\
\hline & & $\mathrm{Cg}$ & 49 & sand & n.d. & n.d. & $0.002 \ldots 0.009$ & $6.3 \ldots 6.5$ & yes \\
\hline & & $\mathrm{Cgf}$ & n.d. & n.d. & n.d. & n.d. & n.d & n.d. & yes \\
\hline \multirow{6}{*}{$\begin{array}{l}\text { Floodplain, } \\
\text { behind levee, } \\
\text { near creek } \\
\text { Floodplain, } \\
\text { behind levee }\end{array}$} & Typic & A & 15 & silt loam & n.d. & n.d & 0.03 & 6.5 & no \\
\hline & \multirow{5}{*}{$\begin{array}{l}\text { Aquorthels, } \\
\text { silty } \\
\text { Ruptic-Histic } \\
\text { Aquorthels }\end{array}$} & $\mathrm{Bg}$ & 48 & silt loam/sand & n.d. & n.d. & $0.02 \ldots 0.03$ & $6.1 \ldots 6.5$ & yes \\
\hline & & $\mathrm{Bf}$ & n.d. & n.d & n.d. & n.d. & n.d. & n.d. & yes \\
\hline & & Oi & 8 & peat + loam & n.d. & n.d. & 0.07 & 6.4 & no \\
\hline & & $\mathrm{Bg}$ & 37 & loam & n.d. & n.d. & $0.02 \ldots 0.04$ & $4.4 \ldots 5.4$ & yes \\
\hline & & Bgf & n.d. & n.d & n.d. & n.d. & n.d. & n.d. & yes \\
\hline
\end{tabular}

a Classification, soil horizon and texture designations according to Soil Survey Staff (2010).

b Soil-physical analyses according to DIN 19683 (1973).

${ }^{\mathrm{c}}$ Determination after removal of inorganic carbon and dry combustion at $900^{\circ} \mathrm{C}$ (DIN ISO 10694 ).

${ }^{\mathrm{d}} \mathrm{pH}$ measured in $0.01 \mathrm{MCaCl}_{2}$ solution (DIN 19684-1, 1977).

e Reductive soil conditions detected by the a-a'-dipyridyl test (Soil Survey Staff, 2010). Data compiled from Fiedler et al. (2004), Kutzbach (2006) and Sanders et al. (2010).

(Wf) While Glacic Aquiturbels show a Glacic Horizon Wf within $1 \mathrm{~m}$ below the soil surface, Typic Aquiturbels do not.

Table 4. Analysis of annual rainfall records for Samoylov Island. $P_{\text {total }}$ : total annual rainfall in mm; NaNs: percentage of missing values, May to end of September; $P_{\text {heavy }}(\%)$ : rainfall events that exceeded $16 \mathrm{~mm}$ (the threshold of $16 \mathrm{~mm}$ is exceeded by only $1 \%$ of all rainfall events); $P_{\text {heavy }}$ (No.): number of rainfall events that exceeded $16 \mathrm{~mm}$. Note that the years 2000, 2003 and 2006 had missing data between 20 to $66 \%$.

\begin{tabular}{|c|c|c|c|c|c|c|c|c|c|c|c|c|c|}
\hline & 1999 & 2000 & 2001 & 2002 & 2003 & 2004 & 2005 & 2006 & 2007 & 2008 & 2009 & 2010 & 2011 \\
\hline$P_{\text {total }}(\mathrm{mm})$ & 88 & 48 & 52 & 105 & 199 & 190 & 193 & 177 & 167 & 168 & 69 & 91 & 65 \\
\hline NaNs $(\%)$ & 1 & 66 & 0 & 5 & 25 & 0 & 0 & 20 & 0 & 3 & 1 & 0 & 0 \\
\hline$P_{\text {heavy }}(\%)$ & 0 & 0 & 0 & 0 & 47 & 43 & 0 & 29 & 13 & 14 & 0 & 0 & 29 \\
\hline$P_{\text {heavy }}$ (No.) & 0 & 0 & 0 & 0 & 3 & 3 & 0 & 2 & 1 & 1 & 0 & 0 & 1 \\
\hline
\end{tabular}

descriptions of the applied methods are given in Westermann et al. (2009), Langer et al. (2011a, b).

Under thawed conditions, the active layer tundra soils in wet polygonal centres had heat capacities of $3.4 \pm 0.5 \mathrm{MJ} \mathrm{m}^{-3} \mathrm{~K}^{-1}$ and thermal conductivities of $0.60 \pm 0.17 \mathrm{~W} \mathrm{~m}^{-1} \mathrm{~K}^{-1}$ (Langer et al., 2011a). Much lower values for $C_{\mathrm{h}}$ were found on the dry ridges, which had heat capacities of $0.9 \pm 0.5 \mathrm{MJ} \mathrm{m}^{-3} \mathrm{~K}^{-1}$ and thermal conductivities of $0.14 \pm 0.08 \mathrm{~W} \mathrm{~m}^{-1} \mathrm{~K}^{-1}$. For frozen conditions in the active layer, the respective values were $C_{\mathrm{h}}=1.8 \pm 0.3 \mathrm{MJ} \mathrm{m}^{-3} \mathrm{~K}^{-1}$ and $K_{\mathrm{h}}=0.95 \pm 0.23 \mathrm{~W} \mathrm{~m}^{-1} \mathrm{~K}^{-1}$ in wet polygonal centres and $C_{\mathrm{h}}=0.7 \pm 0.3 \mathrm{MJ} \mathrm{m}^{-3} \mathrm{~K}^{-1}$ and $K_{\mathrm{h}}=0.46 \pm 0.25 \mathrm{~W} \mathrm{~m}^{-1} \mathrm{~K}^{-1}$ in the dry ridges (Langer et al., 2011b). For perennially frozen permafrost soils, we obtained thermophysical properties from the soil composition of the $4 \mathrm{~m}$ core (Fig. 5) and the soil temperature record of the $4 \mathrm{~m}$ borehole. The average heat capacity was found to be $2.1 \pm 0.05 \mathrm{MJ} \mathrm{m}^{-3} \mathrm{~K}^{-1}$ and the average thermal conductivity was $1.9 \pm 0.4 \mathrm{~W} \mathrm{~m}^{-1} \mathrm{~K}^{-1}$. Both values are significantly higher than in the active layer which is explained by the higher mineral content.

\section{Near-surface: climate and permafrost}

\subsection{Precipitation}

\subsubsection{Rainfall}

Rainfall on Samoylov Island usually occurs between the middle of May and the end of September. From 1999 to 2011 the summer rainfall in years for which a complete record is available varied between a low of $52 \mathrm{~mm}$ in 2001 and a high of $199 \mathrm{~mm}$ in 2003 (Table 4), with a mean of about $125 \mathrm{~mm}$. Seventy percent of the total rainfall events were light, with less than $1 \mathrm{~mm}$ of precipitation (a rainfall event comprises the total precipitation during consecutive hours with rainfall $>0$; if there are less than three hours without rain between two of these events, then these two events are treated as a single event). Only $1 \%$ of the rainfall events recorded 


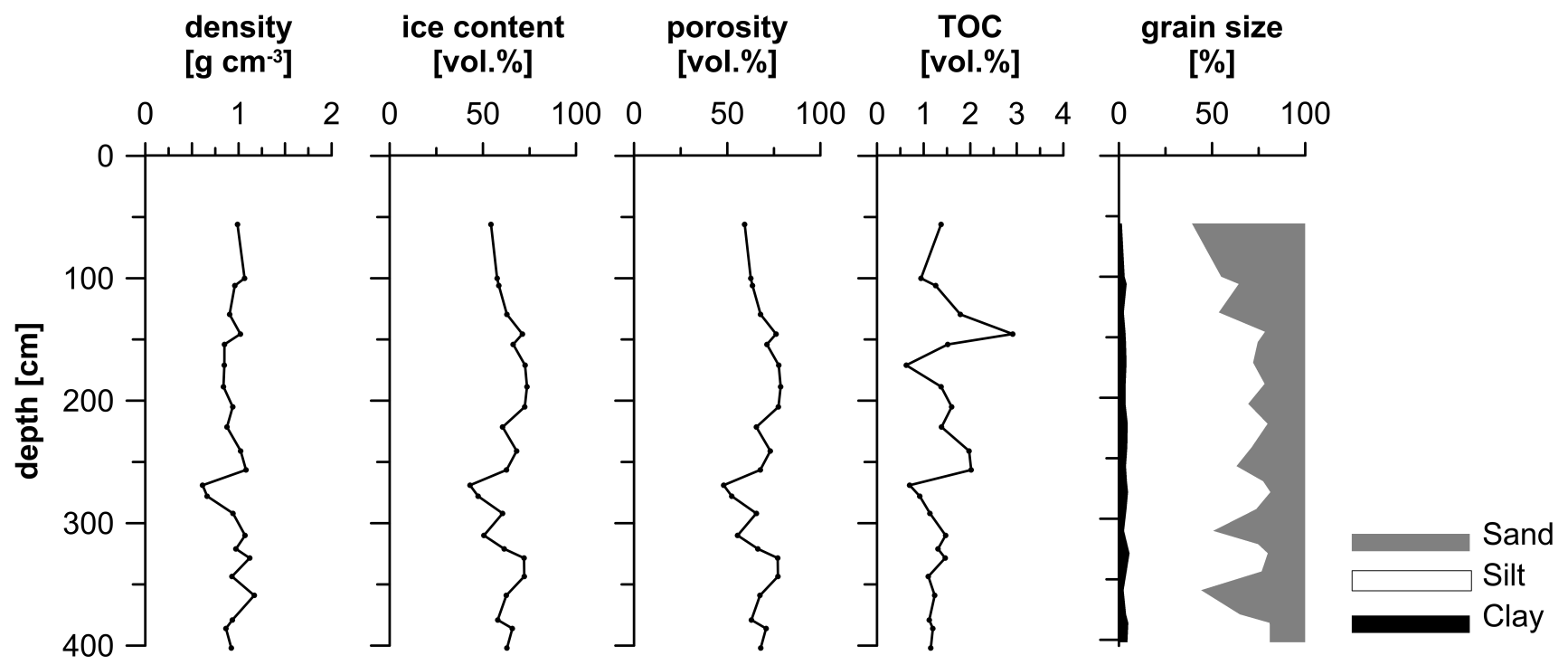

Fig. 5. Physical soil characteristics determined for a $4 \mathrm{~m}$ core of frozen soil from Samoylov Island (close to lake 1; see Fig. 2).

more than $16 \mathrm{~mm}$, these being classed as heavy precipitation events. These heavy precipitation events and their relative contributions to the total annual rainfall are presented in Table 4. In 2006 nearly one third of the total precipitation was contributed by just two individual events. In 2003 and 2004 three events contributed nearly half of the total rainfall.

\subsubsection{Snow cover}

The snow depth shows a high degree of spatial variability. Strong winds redistribute the snow on the island, resulting in bare surfaces on the polygonal rims and polygonal centres filled with snow. The snow consists mainly of very loose, large-grained depth hoar and hardened, sediment-rich layers (Boike et al., 2003). The polygonal micro-topography, thus, combines with the wind to redistribute the snow from the polygon rims towards their centres. During the period between August 1998 and August 2002, snow depth was measured on a polygon rim, after which the station was moved and the snow depth measured in a polygon centre, where it was significantly greater (Table 5 and Fig. 6). During the spring 2008, the snow physical characteristics were examined at 216 sites ( 8 polygon) on the island (Fig. 6). The mean snow depth on the polygon rims was about $17 \mathrm{~cm}$, and in the centres about $46 \mathrm{~cm}$. The average snow density was $195 \mathrm{~kg} \mathrm{~m}^{-3}$, ranging from $175 \mathrm{~kg} \mathrm{~m}^{-3}$ to $225 \mathrm{~kg} \mathrm{~m}^{-3}$ between rims and centres. The total average Snow Water Equivalent (SWE) for the island was, thus, estimated to be 65 $( \pm 35) \mathrm{mm}$. Snow melt usually started in the second half of May and the snow cover had typically disappeared by early June. An exception was in 2004, when the snow only disappeared in the middle of June. In May 2004, snow depths in the polygon centres reached $56 \mathrm{~cm}$, which was the greatest snow depth recorded. The snow-free period usually lasted until sometime in September. The dates for the disappearance of snow and for the renewal of snow accumulation are given in Table 5. The snow-free period was then calculated from these dates, as snow-free days.

In 2008, rainfall contributed $70 \%$ to the total precipitation input and SWE less than $30 \%$.

\subsection{Air temperature and radiation}

The annual mean air temperature on Samoylov Island from 1998-2011 was $-12.5^{\circ} \mathrm{C}$. An analysis of the Samoylov Island air temperature data showed that January and February were generally the coldest months, with mean temperatures of $-30.3{ }^{\circ} \mathrm{C}$ and $-33.1^{\circ} \mathrm{C}$, respectively. The highest mean monthly temperatures occurred in July $\left(10.1^{\circ} \mathrm{C}\right)$ and August $\left(8.5^{\circ} \mathrm{C}\right)$. Figure 7 illustrates the average yearly temperature cycle, with monthly means and their standard deviations. Positive mean monthly temperatures were recorded from June to August. Mean monthly temperatures for September were generally close to zero degrees, but were positive on average. With standard deviations of about $3{ }^{\circ} \mathrm{C}$ from January to May, the air temperature variations were about $1{ }^{\circ} \mathrm{C}$ greater than from June to September (Fig. 7).

The mean annual net radiation was $18 \mathrm{~W} \mathrm{~m}^{-2}$, with positive mean monthly net radiations recorded from May to September. June showed the highest net radiation, with an average of about $120 \mathrm{Wm}^{-2}$. Figure 7 shows the high interannual variability in the net radiation for May and June, which is due to variations in the timing of snow melt (Table 5).

The temporal record of air temperature and net radiation is shown in Fig. 8. No clear warming trend is visible, although winter temperatures during recent years have not been as cold as in earlier years. Of note is the very warm summer of 2010 , 
(a)

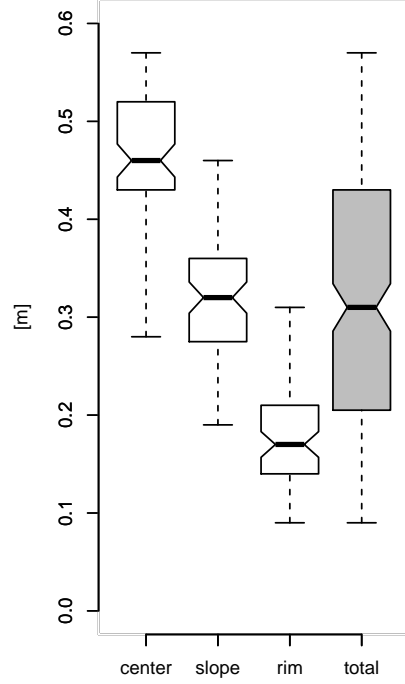

(b)

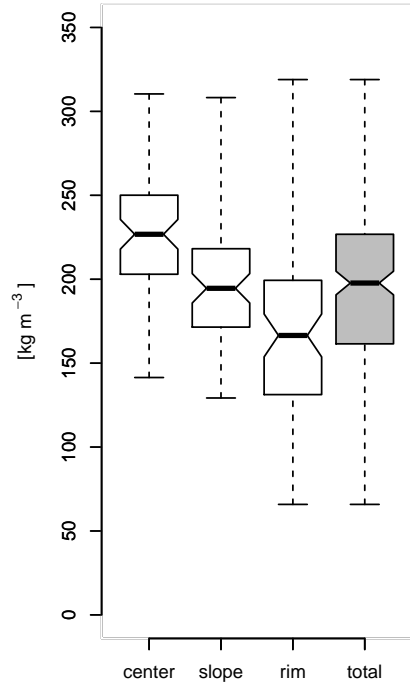

(c)

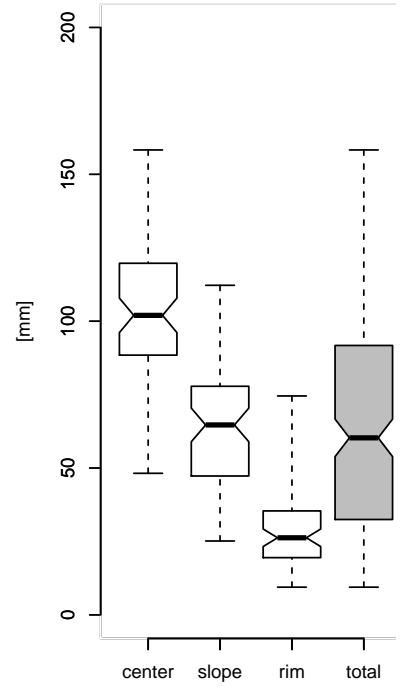

Fig. 6. Box plot of snow depth (a), snow density (b), and snow water equivalent (c), measured on the microtopographic relief of polygon centres, slopes, and rims from 25 April to 2 May 2008, and averaged across Samoylov Island. The box plot shows medians and standard deviations for 216 plots (8 polygons with 9 sites on each of their centrers, slopes, and rims, i.e., 72 centres, 72 rims and 72 slopes).

Table 5. Dates and durations of snow covered periods for the years 1998-2011. The snow height sensor was moved in 2002 (from polygon rim to polygon centre). Note that the snow season overlaps two calendar years. The length of snow season shown for 1999, for example, actually includes days from October 1998 through to May 1999. The total number of days shown in any one "year" is, therefore, variable.

\begin{tabular}{|c|c|c|c|c|c|c|c|c|c|c|c|c|c|c|}
\hline & 1998 & 1999 & 2000 & 2001 & 2002 & 2003 & 2004 & 2005 & 2006 & 2007 & 2008 & 2009 & 2010 & 2011 \\
\hline Snow end date & n.d. & 22 May & 11 May & 15 May & 20 May & 12 May & 16 Jun & 25 May & 7 Jun & 20 May & 26 May & 3 Jun & 9 Jun & $26 \mathrm{Apr}$ \\
\hline Snow start date & 26 Oct & 8 Oct & 19 Oct & 4 Oct & $23 \mathrm{Oct}$ & $21 \mathrm{Oct}$ & $28 \mathrm{Sep}$ & $26 \mathrm{Sep}$ & 3 Oct & 24 Oct & 4 Oct & 15 Oct & 11 Oct & n.d. \\
\hline $\begin{array}{l}\text { Max. snow depth } \\
(\mathrm{cm})\end{array}$ & n.d. & 9 & 13 & 30 & 27 & 28 & 56 & 23 & n.d. & 44 & 36 & 42 & 32 & 27 \\
\hline $\begin{array}{l}\text { Length of snow } \\
\text { season (days) }\end{array}$ & n.d. & 208 & 216 & 208 & 228 & 201 & 239 & 239 & 254 & 229 & 215 & 242 & 237 & 197 \\
\hline $\begin{array}{l}\text { Length of snow-free } \\
\text { season (days) }\end{array}$ & n.d. & 139 & 161 & 142 & 156 & 162 & 104 & 124 & 118 & 157 & 131 & 134 & 124 & n.d. \\
\hline
\end{tabular}

where mean air temperatures in July reached $15.4^{\circ} \mathrm{C}$ concomitant with high net radiation values.

\subsection{Thermal state of the permafrost and the active layer}

The temperature of the permafrost has been recorded from a $27 \mathrm{~m}$ deep borehole since 2006 . The annual average temperature of the active layer of the permafrost $(0.03 \mathrm{~m})$ is $-8.4^{\circ} \mathrm{C}$ (Fig. 9a), which is about $3^{\circ} \mathrm{C}$ warmer than the average air temperature over the same period $\left(-11.6^{\circ} \mathrm{C}\right)$. At a depth of $1.7 \mathrm{~m}$, (well below the active layer), the average soil temperature is slightly higher $\left(-7.8^{\circ} \mathrm{C}\right)$, but then decreases with depth to $-8.6^{\circ} \mathrm{C}$ at $10.7 \mathrm{~m}$ depth and $-8.9^{\circ} \mathrm{C}$ at depths of $20.7 \mathrm{~m}$ and $27 \mathrm{~m}$ (Fig. 9a).

The temperature of the uppermost soil layer ranged from about $20^{\circ} \mathrm{C}$ to $-35^{\circ} \mathrm{C}$ in 2007 . This fluctuation diminished rapidly with depth to only a few degrees at $10 \mathrm{~m}$, and was barely detectable below a depth of $20 \mathrm{~m}$, where the annual temperature variation was less than $0.1^{\circ} \mathrm{C}$.
Figure $9 \mathrm{~b}$ shows the average, maximum and minimum monthly soil temperatures at a depth of $0.21 \mathrm{~m}$. The time series contains measurements from August 2002 to September 2011, obtained from a dry ridge site. February usually showed the lowest soil temperatures, with a mean of $-24.4^{\circ} \mathrm{C}$. The highest mean soil temperatures were usually recorded in August, averaging $4.1^{\circ} \mathrm{C}$. The year to year variations in the mean temperatures were within a range of $3.5^{\circ} \mathrm{C}$ for the months of June through to October. The variations were greater during the rest of the year, particularly during the cooling of the soil in November and December, when variations of up to $10^{\circ} \mathrm{C}$ have been recorded.

Figure 10 illustrates the mean monthly temperatures in the subsurface (dry tundra site, polygon rim), measured from August 1998 to August 2011 close to the surface and at depth of around $50 \mathrm{~cm}$. The range between the highest summer temperatures and the lowest winter temperatures can be more than $30^{\circ} \mathrm{C}$ close to the surface and more than $20^{\circ} \mathrm{C}$ at a depth of around $50 \mathrm{~cm}$. 

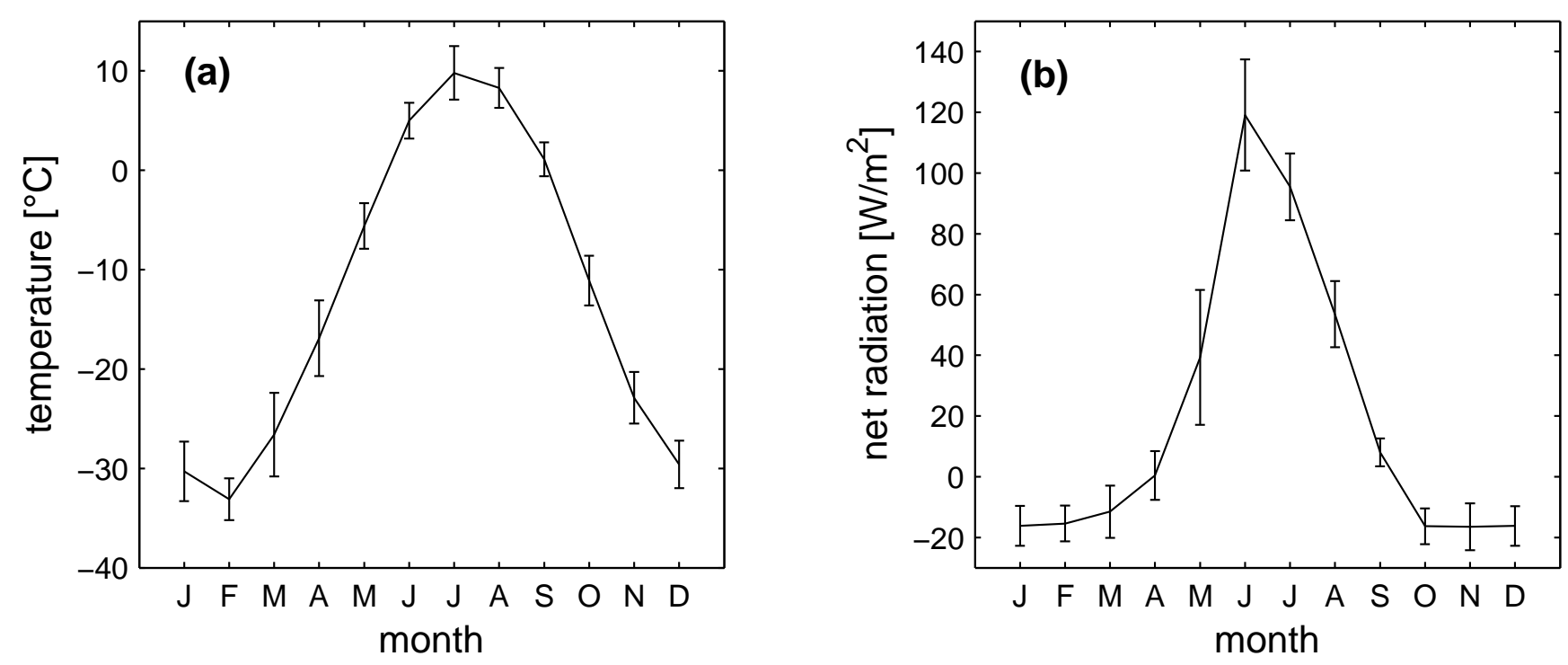

Fig. 7. Air temperature (a), and net radiation (b), measured on Samoylov Island from 1998-2011. The bars are standard deviations of the monthly means.

Table 6 provides an overview of thaw depths from 1998-2011. Autumnal isothermal conditions $\left(\right.$ at $\left.0{ }^{\circ} \mathrm{C}\right)$ and freeze-back started at the end of September or beginning of October and it usually took more than a month for the active layer to refreeze (end of freeze-back: Table 6). Due to the large latent heat content of the water-saturated wet tundra, the freeze-back takes up to 14 days longer in those areas than in the drier areas (Table 6).

Figure 11 shows the temperatures measured in the deep borehole since 2006 , at depths of 10.7 and $20.7 \mathrm{~m}$. Since 2006, a warming has been detected of about $0.4^{\circ} \mathrm{C}$ at $20.7 \mathrm{~m}$ and $1.3{ }^{\circ} \mathrm{C}$ at $10.7 \mathrm{~m}$.

\subsection{Spatial variability of active layer thickness}

The active layer, which is characterised by seasonal freezing and thawing, exhibits a large amount of spatial and temporal variability. The soil moisture characteristics at the 150 sites from which measurements of the thaw depth have been taken (Sect. 2), have been qualitatively evaluated by Muster et al. (2012), resulting in 106 of the sites being classified as "dry tundra" and 44 as "wet tundra" (Fig. 12a, b).

Thawing of the soil usually started in early to mid-June. The wet tundra areas had a slightly greater mean thaw depth $(19 \mathrm{~cm})$ than the dry areas $(15 \mathrm{~cm})$ in June, but this small difference was further reduced in the remaining months from July to September. In August, the mean thaw depth was about $49 \mathrm{~cm}$, with a maximum of $79 \mathrm{~cm}$ (dry) and $61 \mathrm{~cm}$ (wet). The highest thaw rates occurred in June and July when the net radiation input was at its greatest (Fig. 7), with only limited further thawing in August and early to mid-September. The averaged values are generally very similar, but a high variability in thaw depth can be seen when the range of minimum and maximum values is considered. The statistics are, however, much the same for both dry and wet tundra, with similar means, similar thaw depths at the 25 and $75 \%$ quantiles, and a large spread between minimum and maximum values.

\section{Hydrosphere}

\subsection{Characteristics of water bodies}

The thermal dynamics of those polygonal ponds and thermokarst lakes that are not flooded annually were evaluated for periods covering (i) the start of ice cover formation (for ponds this is when the sensor's temperature falls below $0^{\circ} \mathrm{C}$, and for thermokarst lakes, where the uppermost sensor is usually well below the surface, the date chosen is the inferred start of stratification), (ii) frozen winter conditions (the date from which the lowermost sensor, which is generally at or close to the bottom, records temperatures below $0{ }^{\circ} \mathrm{C}$ ), (iii) ice break-up (from first ice melt to the complete disappearance of ice, defined as starting when the uppermost sensor's temperature rises above $0^{\circ} \mathrm{C}$ and sensors at depth show pronounced warming trends), and (iv) stratification (when thermal layering is detectable from the temperature profile). Details are provided below over the 2010-2011 annual cycle for three polygonal ponds ("pond stations"; Fig. 2) and for four thermokarst lakes (Fig. 2).

\section{Ponds}

The shorelines of polygonal ponds are defined by icewedge structures and their profiles are u-shaped, with steep flanks and a flat bottom. The depths of the 103 ponds 
Table 6. Duration of active layer thaw and freeze of polygon rim and centre (days) and thaw depths (cm), for the years 1998-2011. The differences between the water saturated centre and the dry rim are only available from 2002 to 2011 . The start of freeze-back was determined as the time when temperatures in all thawed layers had fallen to $0^{\circ} \mathrm{C}$. The end of freeze-back was determined as the time when the volumetric water content (using Time Domain Reflectometry) reached, and remained at, its minimum. Note that the soil instrumentation was moved in 2002. Thaw depths in 2007 and 2009 were determined in mid-August, and for all other years at the end of August.

\begin{tabular}{|c|c|c|c|c|c|c|c|c|c|c|c|c|c|c|}
\hline & 1998 & 1999 & 2000 & 2001 & 2002 & 2003 & 2004 & 2005 & 2006 & 2007 & 2008 & 2009 & 2010 & 2011 \\
\hline Start of thaw & n.d. & 3 Jun & ND & 5 Jun & 29 Мау & 8 Jun & 15 Jun & 7 Jun & 1 Jun & 1 Jun & $12 \mathrm{Jun}$ & 11 Jun & 8 Jun & $1 \mathrm{Jun}$ \\
\hline $\begin{array}{l}\text { Start of freeze-back } \\
\text { (rim) }\end{array}$ & $23 \mathrm{Sep}$ & n.d. & $25 \mathrm{Sep}$ & 8 Sep & $14 \mathrm{Sep}$ & 2 Oct & 29 Sep & 4 Oct & 8 Oct & 6 Oct & $26 \mathrm{Sep}$ & 5 Oct & $2 \mathrm{Oct}$ & n.d. \\
\hline $\begin{array}{l}\text { End of freeze-back } \\
\text { (centre) }\end{array}$ & n.d. & n.d. & n.d. & n.d. & $19 \mathrm{Nov}$ & $4 \mathrm{Dec}$ & $17 \mathrm{Nov}$ & n.d. & $19 \mathrm{Nov}$ & $16 \mathrm{Dec}$ & n.d. & $8 \mathrm{Dec}$ & $4 \mathrm{Dec}$ & n.d. \\
\hline $\begin{array}{l}\text { Max. thaw depth } \\
\text { (polygon) }\end{array}$ & n.d. & n.d. & n.d. & n.d. & 43 & 48 & n.d. & 50 & 45 & 52 & 54 & 42 & 56 & 57 \\
\hline $\begin{array}{l}\text { Mean ground temp. } \\
@ 47 / 51 \mathrm{~m} \text { depth } \\
\text { (May) }\left({ }^{\circ} \mathrm{C}\right)\end{array}$ & n.d. & -11.3 & n.d. & -11.5 & -11.9 & -7.7 & -13.4 & -10.8 & -5.7 & -8.7 & -10.4 & -13.4 & -2.5 & -6.0 \\
\hline $\begin{array}{l}\text { Mean ground temp. } \\
\text { @ } 47 / 51 \mathrm{~m} \\
(\mathrm{Jul})\left({ }^{\circ} \mathrm{C}\right)\end{array}$ & n.d. & 0.3 & n.d. & 2.0 & 2.7 & -0.6 & -1.3 & -0.9 & -1.0 & -0.6 & -1.0 & -1.2 & -0.8 & -0.7 \\
\hline
\end{tabular}

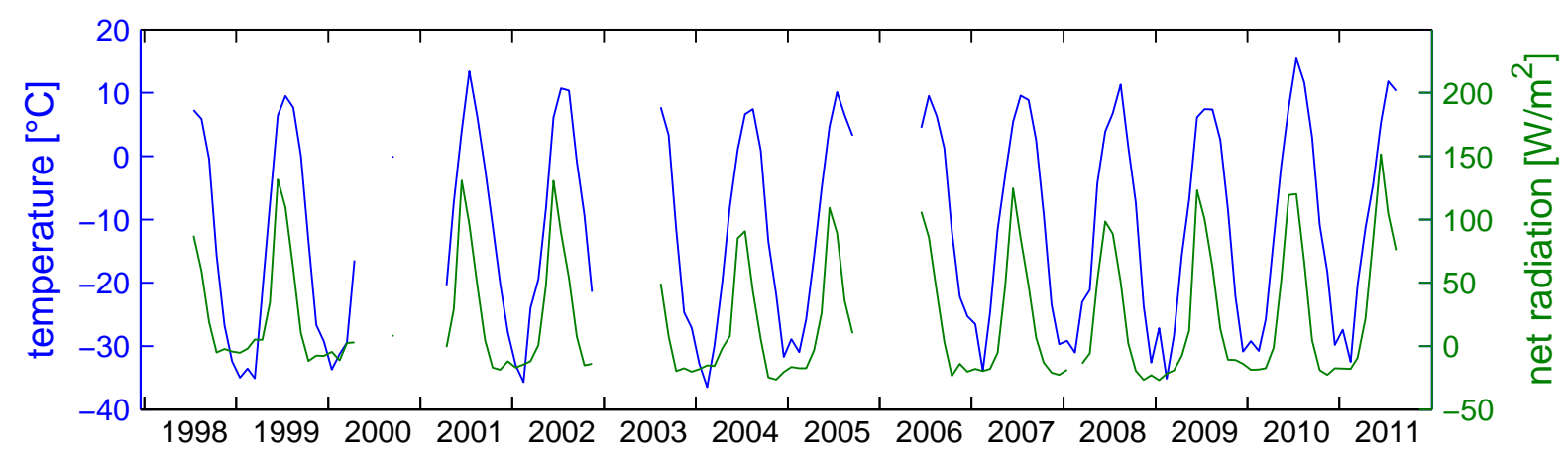

Fig. 8. Mean monthly air temperature and net radiation record for Samoylov Island, 1998- -2011.

surveyed ranged from a few centimetres to $1.3 \mathrm{~m}$. The surface of the ponds started to freeze at the end of September $(\sim 29$ September in 2010; Fig. 13). During the winter there was a clear temperature gradient from the surface to the bottom. In all three ponds the ice cover started to break up at the end of April, but they subsequently refroze as air temperatures again dropped below zero during May.

In general, all three ponds were well mixed during the summer months (June, July and August). However, on a daily time scale (not shown) the lowermost sensors in the shallower ponds (Ponds 1 and 3) indicated a degree of stratification, i.e., they showed slightly colder temperatures than the sensors above. Maximum water temperatures reached $\sim 18^{\circ} \mathrm{C}$ in Pond $2,20^{\circ} \mathrm{C}$ in Pond 1 , and $23^{\circ} \mathrm{C}$ in Pond 3. Ponds 1 and 3 reacted very quickly to subsequent cooling and were frozen to the bottom by mid-November (by $\sim 15$ November in 2010). Pond 2 took two months longer (until $\sim 20$ January 2011) for bottom temperatures to fall below zero. Differences between the ponds are not only de- tectable during freeze-up of the ponds, but also during ice break-up. On 29 May, water temperatures in Ponds 1 and 3 started to rise over the entire profile; this occurred 7 days later in Pond 2. The different dates could be due to bathymetric differences between the ponds (Ponds 1 and 3 have shallower and more irregular profiles than Pond 2), or to variations in the amount of vegetation present.

\section{Thermokarst lakes}

The shorelines of the shallow parts of thermokarst lakes $(0-3 \mathrm{~m}$ depth) are very irregular and feature protrusions of different shapes and sizes. When deeper sections $(>3 \mathrm{~m})$ occur close to the shore, the shorelines are smooth and the lakes have an oval shape. In contrast to ponds the bottoms of thermokarst lakes are not flat and the profiles are more $\mathrm{v}$-shaped. The thermokarst lakes were up to $6.1 \mathrm{~m}$ deep. 

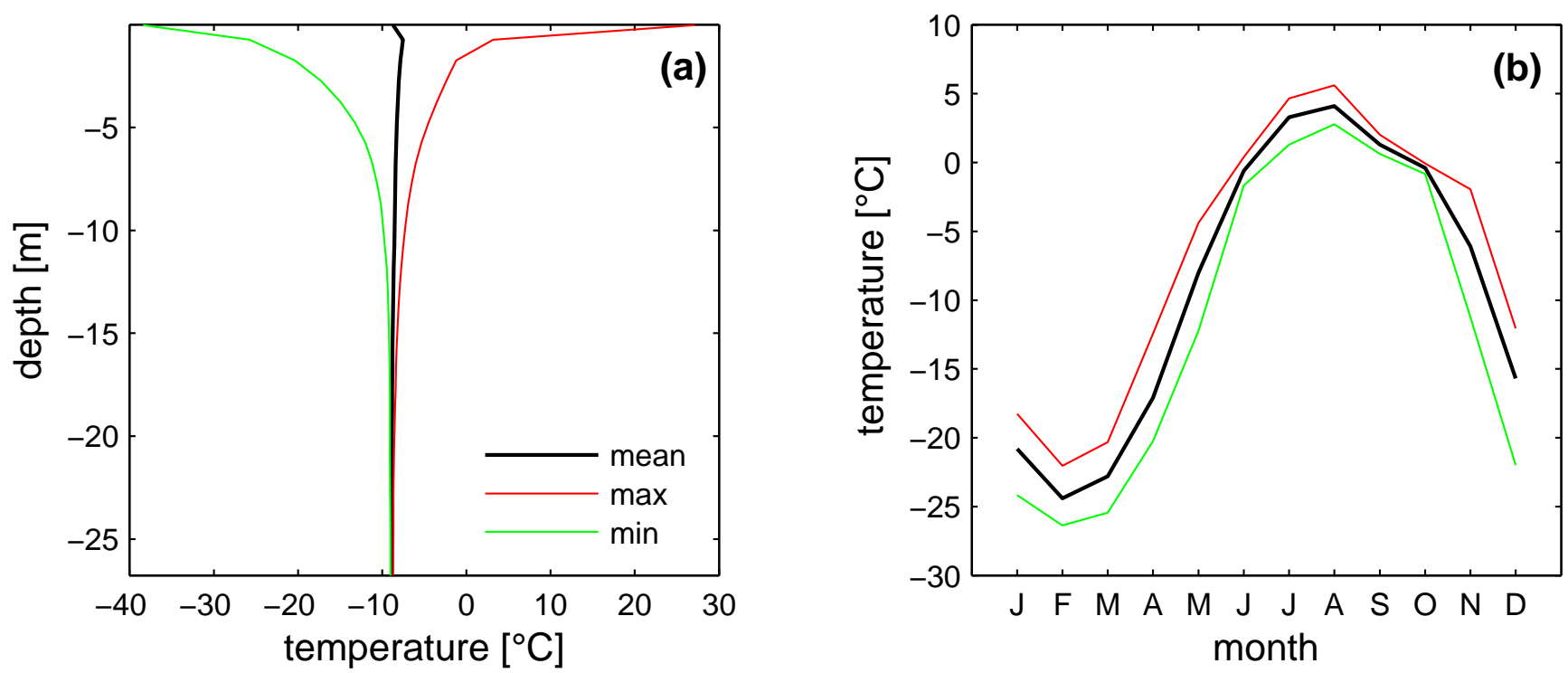

Fig. 9. Mean, maximum, and minimum monthly temperatures for the deep (27 m) borehole on Samoylov Island, from $2006-2011$ (a), and mean, maximum, minimum monthly temperature for a polygon dry rim site (0.21 m depth) from 2002-2011 (b).

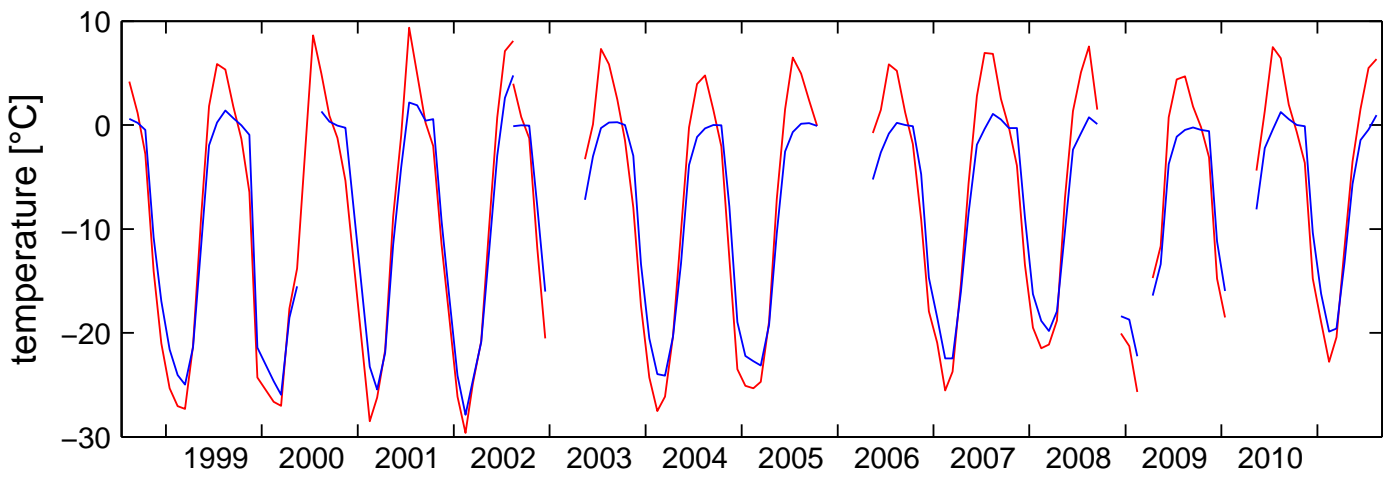

Fig. 10. Record of mean monthly soil temperatures for active layer at polygon rim site on Samoylov Island, 1998-2011. Red line from 19982002 is from a sensor depth of $0.09 \mathrm{~m}$, and from 2002-2011 is from a sensor depth of $0.06 \mathrm{~m}$. Blue line from 1998-2002 is from a sensor depth of $0.47 \mathrm{~m}$ and from 2002-2011 is from a sensor depth of $0.51 \mathrm{~cm}$.

Figure 14 summarises the thermal records for three thermokarst lakes (Lakes 1-3, Fig. 2) between August 2010 and August 2011. Lake 4 in Fig. 2 was excluded from the analysis since it is subject to annual flooding by the Lena River during the spring melt. At the end of September, when the ice cover started to build up, the water columns in the three lakes were isothermal and cooled down to zero degrees. Within just a few days the water temperatures in the deeper parts of the lakes then started to increase and the water columns changed from isothermal to fully stratified. None of the three lakes froze to the bottom in winter. Stratification in Lakes 1 and 2 was not restricted to the winter period, but also occurred in summer. While this only occurred for short periods in July in Lake 2, it was the normal situation in Lake 1, which had only brief periods of full mixing. During the winter months the temperatures were fairly stable, with a grad- ual cooling of $1^{\circ} \mathrm{C}$ at all depths from October to mid-April. Around 24 April there was a clear temperature rise detectable in all three lakes, probably due to the start of ice break-up as a result of snow melt (Table 5). As a first order approximation the ice was considered to have melted completely by the earliest date of complete mixing, which occurred in all three of the thermokarst lakes by mid- to late June. Lake 3 did not develop any stratification during the summer because it is shallower than the other two lakes. Maximum water temperatures in the lakes during summer 2011 ranged from about $16^{\circ} \mathrm{C}$ to $19^{\circ} \mathrm{C}$ (Table 7).

\subsection{Water budget of the polygonal tundra}

The water budget for the polygonal tundra of Samoylov Island consists of vertical inputs and outputs (precipitation and evapotranspiration), the storage of water in water bodies 
Table 7. Comparison between polygonal ponds and thermokarst lakes.

\begin{tabular}{|c|c|c|c|c|c|c|}
\hline & \multicolumn{3}{|c|}{ Thermokarst lakes } & \multicolumn{3}{|c|}{ Polygonal ponds } \\
\hline & Lake 1 & Lake 2 & Lake 3 & Pond 1 & Pond 2 & Pond 3 \\
\hline Area $\left(\mathrm{m}^{2}\right)$ & 39542 & 39991 & 23066 & 164 & 248 & 178 \\
\hline Max. depth (m) & 6.1 & 5.7 & 3.4 & 0.84 & 1.22 & 0.86 \\
\hline Volume $\left(\mathrm{m}^{3}\right)$ & 106500 & 103600 & 18800 & 75 & 300 & 75 \\
\hline Start of ice cover & 30.09 & 29.09 & 28.09 & 23.09 & 13.10 & 29.09 \\
\hline Frozen to bottom & - & - & - & 12.11 & 10.01 & 15.01 \\
\hline Ice break-up & $\begin{array}{l}23 \text { Apr- } \\
19 \text { Jun }\end{array}$ & $\begin{array}{l}25 \mathrm{Apr}- \\
18 \mathrm{Jun}\end{array}$ & $\begin{array}{l}23 \text { Apr- } \\
11 \text { Jun }\end{array}$ & 30 May & 6 Jun & 29 May \\
\hline Stratification & $\begin{array}{l}\text { winter and } \\
\text { summer }\end{array}$ & $\begin{array}{l}\text { winter and } \\
\text { summer }\end{array}$ & - & $\sim$ summer & - & $\sim$ summer \\
\hline Max. temp. $\left({ }^{\circ} \mathrm{C}\right)$ & 17.6 & 15.9 & 18.7 & 19.8 & 16.9 & 23.0 \\
\hline
\end{tabular}

(lakes and ponds) and in the active layer of soils, and horizontal fluxes (surface and subsurface runoff). Long-term moisture measurements for the active layer have been recorded at a soil and climate station (Fig. 2) since 1998. The microtopography of the polygons had a strong effect on the spatial distribution pattern of soil moisture: the polygon centre was typically water saturated throughout the seasonal thaw period of the active layer, while the polygon rim was generally unsaturated to a depth of between 5 and $15 \mathrm{~cm}$ below the surface (further details available in Boike et al., 2008, 2012). Measurements of water levels and horizontal fluxes were initiated in 2008. However, in this subsection we consider the water balance of the site within a longer term perspective (1958 to 2011), using the understanding of processes obtained from detailed field investigations. In addition to micrometeorological measurements of evapotranspiration and precipitation (both liquid and solid), water budget measurements (including discharge rates and water levels) were collected during 2008 (see Fig. 2 for measurement locations). The seasonal water budget estimate for Samoylov Island for 2008 showed that losses through evapotranspiration (ET) were offset by similar inputs from precipitation $(P)$, resulting in a state of approximate equilibrium in the investigated water bodies (ponds and lakes) prior to freeze-back (Table 8). The evapotranspiration rates from July to midSeptember averaged about $1.3 \mathrm{mmday}^{-1}$, with a maximum of $3.7 \mathrm{~mm} \mathrm{day}^{-1}$ (14 July). Lake (and pond) water levels varied by less than $10 \mathrm{~cm}$ in 2008 . The overall water balance was positive from April to September 2008, with the total precipitation input of about $233 \mathrm{~mm}(65 \mathrm{~mm} \mathrm{SWE}+168 \mathrm{~mm}$ rain) being greater than the losses due to evapotranspiration $(\sim 190 \mathrm{~mm})$. The total snow water equivalent recorded in April was about $65 \mathrm{~mm}$ and only $15 \mathrm{~mm}$ of this input was lost to evaporation in May (Table 8). The summer rainfall (June-September) totalled $\sim 162 \mathrm{~mm}$, the wettest month being June $(\sim 60 \mathrm{~mm})$. The total runoff from the island during the summer was negligible relative to the vertical fluxes (precipitation and evapotranspiration). However, it is not possible

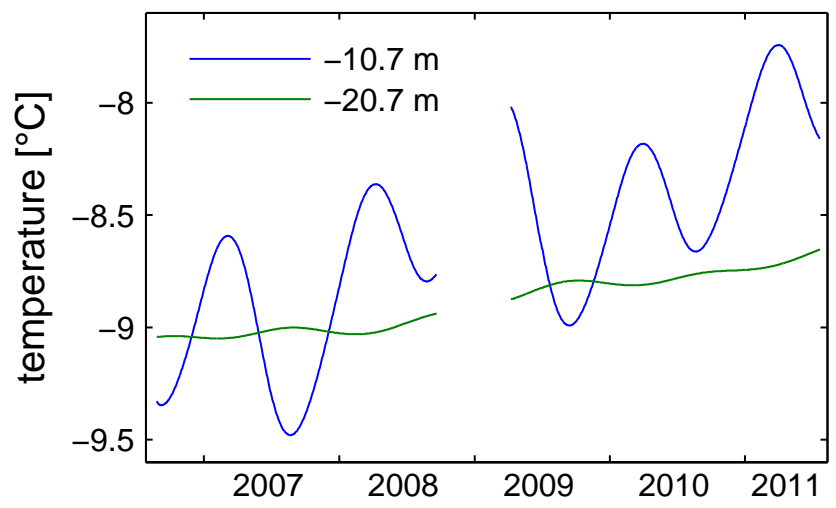

Fig. 11. Daily mean temperatures at depth in permafrost, 20062011. Data from deep borehole, Samoylov Island.

to close the water balance since no runoff measurements exist from the snow-melt period. The water balance is nevertheless dominated by precipitation and evapotranspiration, while lateral fluxes are less important.

The long-term water budget, i.e., precipitation minus evapotranspiration $(P-\mathrm{ET})$, modelled for the Samoylov Island site since 1958, on the basis of ERA reanalysis data (ECMWF, http://www.ecmwf.int/), is shown in Fig. 15. Evapotranspiration was calculated for the summer months (June to the end of September) using the Thornthwaite model (Thornthwaite, 1948). Since this model was originally designed for temperate climates and uses day length and air temperature as inputs, it potentially overestimates evapotranspiration since the length of a polar day is not taken into account. For Samoylov Island the model was calibrated over several years (2003-2009) using eddy covariance data obtained from the sites shown in Fig. 2, resulting in a Thornthwaite evapotranspiration correction factor of 0.35 . The longterm water budget was roughly balanced, tending towards positive values $(P>$ ET, Fig. 15$)$, which is in agreement with the more detailed analysis from 2008. Furthermore, there is an agreement between the qualitative indicators of the water 

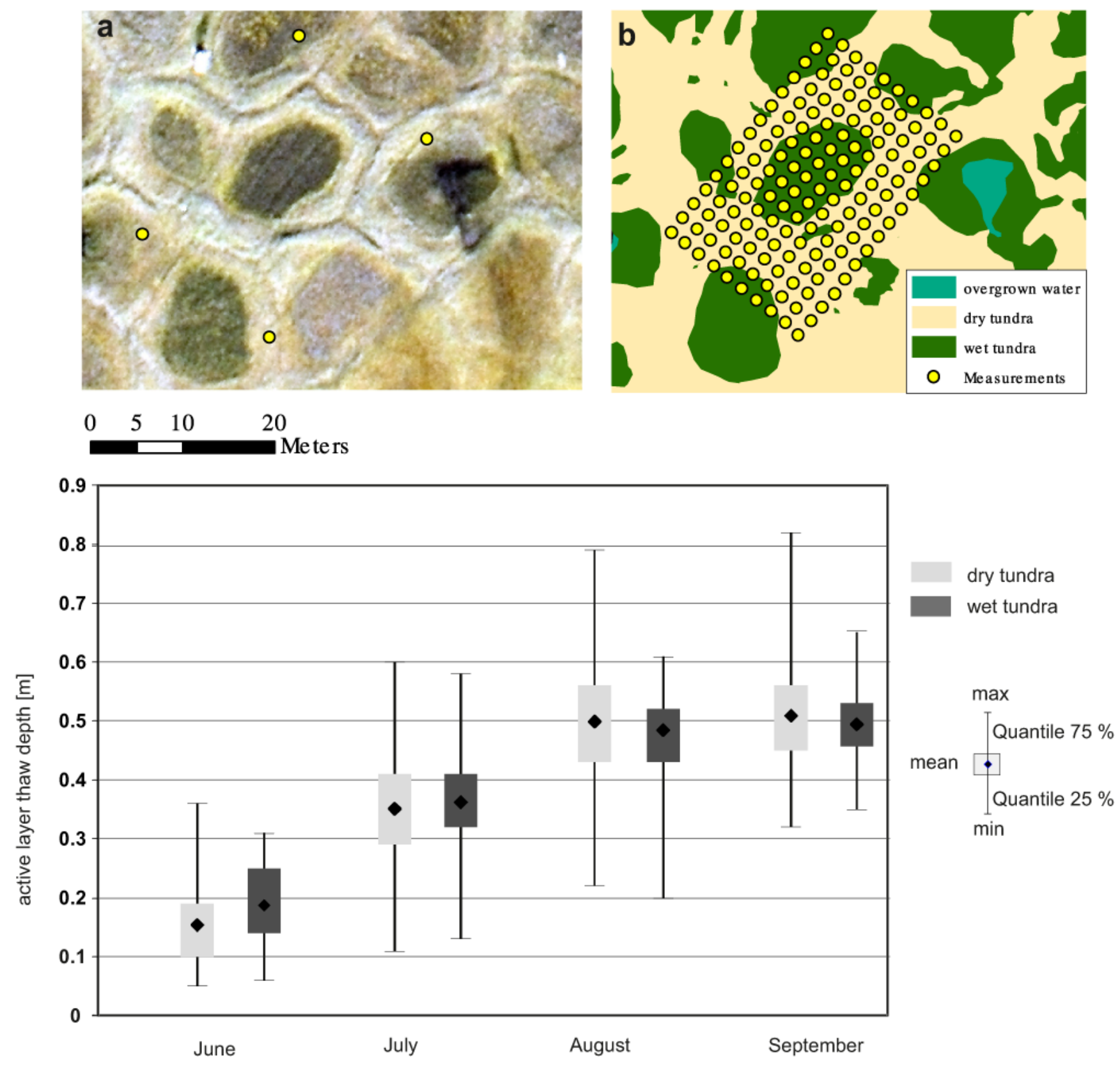

Fig. 12. Active layer thaw depth measurement sites since 2002. (a) Aerial image with $27.5 \times 18 \mathrm{~m}$ measurement grid (150 data points) marked by four outer grid points, (b) classification according to Muster et al. (2012), and (c) monthly statistics (June-September, 2002-2011) for active layer thaw depth, for dry and wet tundra classifications. The box plot shows summary statistics of mean, min./max. (whiskers), and 25 and $75 \%$ quantile ranges for each month.

balance determined from aerial images (visualised qualitatively as the "fill" status of the ponds and lakes) and the modelled $(P$-ET) water balance.

The CORONA satellite image from 1968 indicates a drier tundra landscape with ponds dried up or shrunken thermokarst lakes (see, for example, inside the circles marked on the lower images in Fig. 15). Lake 3 had almost completely disappeared, Lakes 1 and 2 showed greatly re- duced water levels, and there had been a widespread reduction in the water levels of ponds and lakes. The years 1964, 2007 and 2008 represent normal years with positive water balances $(P>$ ET $)$, whereas the dry year in $1968(P<$ ET $)$ is atypical (Fig. 15). This is in agreement with the modelled negative water balance and is a consequence of reduced precipitation. Field observations from 1999 also indicated a dry tundra during that year. From June to August 1999, 
the water level in the centre of the monitored polygon centre fell by total of $15 \mathrm{~cm}$ (from $10 \mathrm{~cm}$ above the ground surface to $5 \mathrm{~cm}$ below the ground surface) due to the negative water balance that resulted from only $56 \mathrm{~mm}$ of rainfall input and a loss of $170 \mathrm{~mm}$ through evapotranspiration (Boike et al., 2008). Rainfall of about $22 \mathrm{~mm}$ in September at least partly refilled the active layer storage prior to freeze-back.

\section{Discussion: how does this site compare with other continuous permafrost sites in the Arctic tundra?}

\subsection{Land cover classification and soils}

The polygonal tundra on Samoylov Island lies within ice-rich permafrost terrain that is characterised by ubiquitous water bodies. Similar wetland landscapes cover about 3-8\% of the Arctic landmass, mostly located in the Arctic coastal plains of Alaska, the Canadian Mackenzie delta and the low-lying wetlands of Northern Siberia (Mackay, 1972, 2002; Washburn, 1979; Gersper et al., 1980; Ping et al., 2004; Tarnocai and Zoltai, 1988; Naumov, 2004; Minke et al., 2007; Webber, 1978; Webber and Walker, 1975; Webber et al., 1980; Walker et al., 2005). The soils of Samoylov Island can be considered typical of Arctic fluvial landscapes. The variety of floodplain soils found in the western part of Samoylov Island can, therefore, also be expected to be present on other active floodplains in the Arctic region. Similarly, polygonal tundra and soils similar to those investigated in the eastern part of Samoylov Island can be expected to form on other Arctic river terraces that are no longer flooded on a regular basis. However, at polygonal tundra sites in which fluvial and aeolian sedimentation processes are less active than in the Lena River Delta, the soils often show greater autochthonous accumulations of organic matter (e.g., Minke et al., 2007, 2009). The Soil Organic Carbon Content (SOCC) was $28 \mathrm{~kg} \mathrm{~m}^{-2}$ for the upper $100 \mathrm{~cm}$ and $73 \mathrm{~kg} \mathrm{~m}^{-2}$ for the upper $300 \mathrm{~cm}$ of one core on Samoylov Island, which is comparable to the average SOCC figure for turbel soils (turbel soils contain on average $32.2 \mathrm{~kg} \mathrm{~m}^{-2}$ in first the $100 \mathrm{~cm}$, with a range from 1 to $126 \mathrm{~kg} \mathrm{~m}^{-2}$, Tarnocai et al., 2009).

\subsection{Climate and permafrost}

According to the Köppen-Geiger classification, this polar tundra climate is representative of the climate found around the northern edges of the North American and Eurasian land masses, and on nearby islands (Peel et al., 2007). Using this classification, the "polar E" climate zone only represents $3.8 \%$ of Asia and $11 \%$ of North America (Peel et al., 2007). The Samoylov Island site is characterised by a large temperature range of $44^{\circ} \mathrm{C}$ between the mean temperatures of the coolest and warmest months. The temperature ranges reported from other Arctic sites with intensive investigations are generally lower, with $29^{\circ} \mathrm{C}$ in the Kevo area of Northern Finland (Harding et al., 2002), $26^{\circ} \mathrm{C}$ in Nome,
Table 8. Water balance estimates for Samoylov Island in 2008. Precipitation $(P)$ includes snow water equivalent in April (from snow transects), and rainfall measured in a tipping bucket gauge as well as manually. Evapotranspiration (ET) was derived from eddy covariance measurements (Langer et al., 2011). Runoff $(Q)$ figures for the island are only available from mid-July.

\begin{tabular}{lrrr}
\hline & $P(\mathrm{~mm})$ & ET $(\mathrm{mm})$ & $Q(\mathrm{~mm})$ \\
\hline Apr & & & \\
(SWE) & 65.0 & & - \\
May & 5.5 & -15.3 & n.d. \\
Jun & 59.9 & -52.2 & n.d. \\
Jul & 39.1 & -55.6 & -1.4 \\
Aug & 42.6 & -43.8 & -2.1 \\
Sep & 20.6 & -23.0 & -1.3 \\
Total & 232.7 & -189.9 & n.d. \\
\hline
\end{tabular}

Alaska (Beringer et al., 2005), $31.8^{\circ} \mathrm{C}$ in Barrow, Alaska and $37.8^{\circ} \mathrm{C}$ in Resolute, Canada (Eugster et al., 2000).

The mean total summer rainfall of $125 \mathrm{~mm}$ on Samoylov Island is comparable to the $86 \mathrm{~mm}$ at Barrow, Alaska (Liljedahl et al., 2011). The percentage of rainfall contributing to total precipitation (in 2008, rainfall contributed $70 \%$ to the total precipitation input and SWE less than $30 \%$ ) is also similar to Barrow, where rainfall comprises from $20 \%$ to $60 \%$ of the total precipitation (Liljedahl et al., 2011). In Alaska and Canada north of $50^{\circ} \mathrm{N}$, snowfall contributes between 40 and $80 \%$ of the total precipitation (Eugster et al., 2000).

The mean net radiation from June to August showed a variability ranging from a low of $73 \mathrm{~W} \mathrm{~m}^{-2}$ in 2004 to a high of $101 \mathrm{~W} \mathrm{~m}^{-2}$ in 1999 . This is mostly due to the high variability in June net radiation caused by variations in the timing of snow melt. The mean June to August net radiation of $85 \mathrm{~W} \mathrm{~m}^{-2}$ is lower than that reported from most other Arctic sites. Examples from other areas include $102 \mathrm{~W} \mathrm{~m}^{-2}$ for the entire growing season at a coastal fen in Greenland (Soegaard et al., 2001), $109 \mathrm{~W} \mathrm{~m}^{-2}$ for June to August at a coastal wetland complex near Prudhoe Bay, North Slope of Alaska (Lynch et al., 1999), and $114 \mathrm{~W} \mathrm{~m}^{-2}$ for the period from 9 June to 29 August at Kaamanen in Northern Finland (Lloyd et al., 2001). Only at Ny-Ålesund, Spitsbergen, have similar net radiation values of $86 \mathrm{~W} \mathrm{~m}^{-2}$ been recorded (Lloyd et al., 2001).

In contrast to net radiation, the timing of snow melt is comparable to that in other Arctic sites. There is, however, a large variability in the end of snow melt between the different years examined. A high variability in the annual end of snow melt has also been reported from Barrow, Alaska, where the dates varied from 22 May to 22 June between 1940 and 2003 (Hinzman et al., 2005). Typical dates for end of snow melt reported from other Arctic and sub-Arctic sites are also within this range, for example, early June at Churchill, Manitoba (Eaton and Rouse, 2001) and the end of May at Kaamanen, 

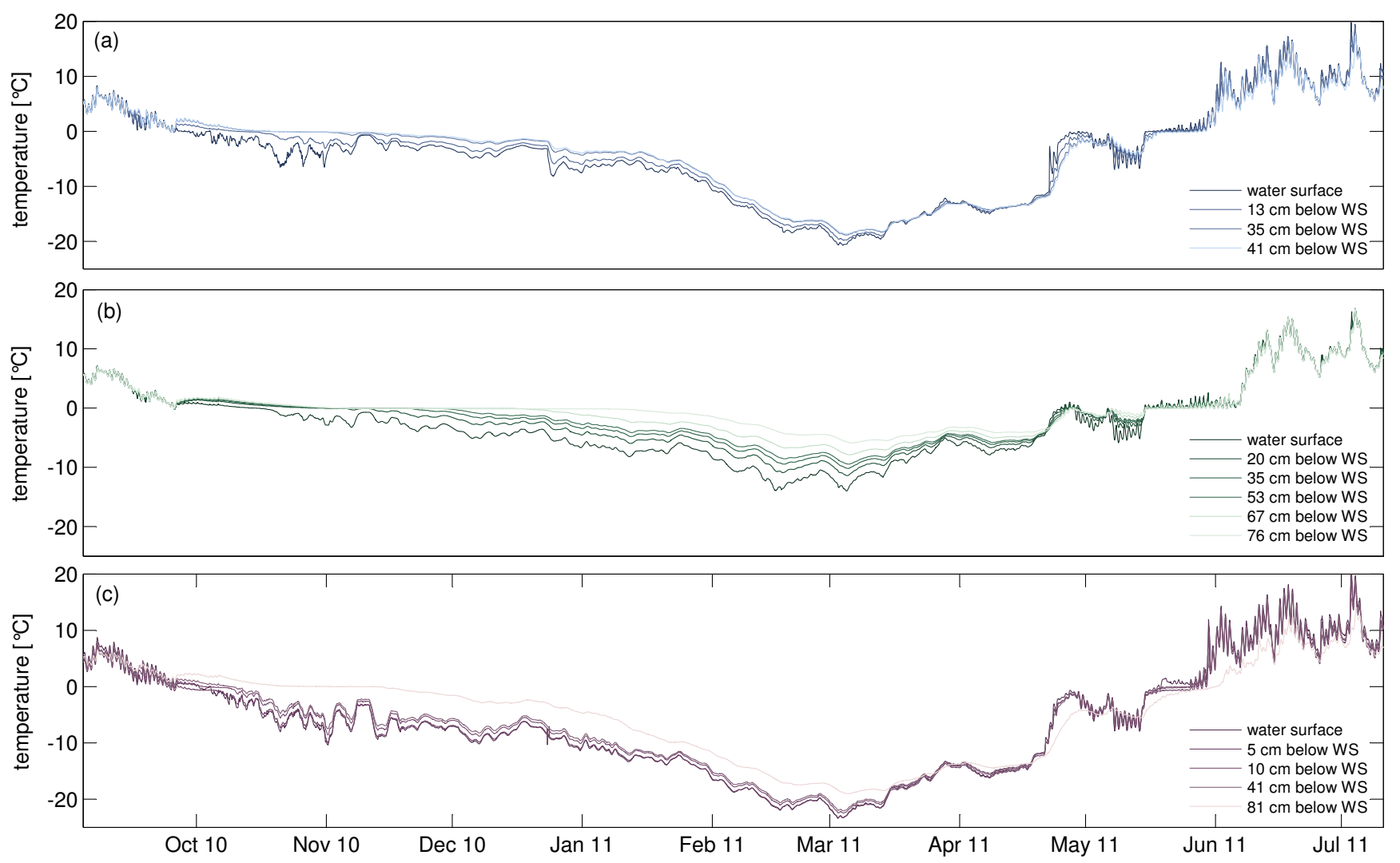

Fig. 13. Temperature dynamics in three polygonal ponds for 2010-2011: (a) Pond 1, (b) Pond 2, and (c) Pond 3.

Northern Finland (Lloyd et al., 2001). Later snow melt (at the end of June) has been reported from Zackenberg, Greenland, and from Ny-Ålesund, Spitsbergen (Lloyd et al., 2001).

With a mean annual permafrost temperature of $-8.6^{\circ} \mathrm{C}$ at $10.7 \mathrm{~m}$ depth, the study site is one of the coldest permafrost regions on earth (Romanovsky et al., 2010a). Brown and Romanovsky (2008) have presented records of permafrost temperatures from 27 circumpolar sites in the Northern Hemisphere. Comparable temperatures have been reported from West Dock in Northern Alaska (near Prudhoe Bay), and from Tiksi, which is $110 \mathrm{~km}$ southeast of Samoylov Island. The annual range of daily mean surface temperatures on Samoylov Island is nearly $39.3^{\circ} \mathrm{C}$, which is higher than the range of $35.4{ }^{\circ} \mathrm{C}$ reported by Hinkel et al. (2001) from Barrow, Alaska. The difference can perhaps be explained by the greater air temperature amplitudes and thinner snow cover on Samoylov Island.

Since the start of permafrost temperature observations on Samoylov Island in 2006, the temperatures at depths of 10 and $20 \mathrm{~m}$ have increased continuously, as has also been reported from permafrost observatories in Northern Alaska (Romanovsky et al., 2010b). A general increase in permafrost temperatures has also been observed over the last few decades in Alaska (Romanovsky et al., 2007, 2010b; Osterkamp, 2008; Smith et al., 2010), Northwest Canada (Smith et al., 2010), and Siberia (Oberman, 2008; Romanovsky et al., 2010a).

\subsection{Hydrosphere: thermal characteristics of ponds and thermokarst lakes, and their water budgets}

Ponds are generally well mixed and experience high water temperatures during the summer and are, therefore, hotspots for biological activity and $\mathrm{CO}_{2}$ emission (Abnizova et al., 2012). The ponds in the study area freeze completely in winter, but the timing of freeze-back can vary by up to 2 months depending on the surface energy balance (Langer et al., 2011b). The deep thermokarst lakes do not freeze to the bottom during the winter and are, therefore, underlain by a zone of thawed material. These deep thermokarst lakes are thermally stratified during winter, which is also typical of Arctic lakes in the Toolik area, Alaska (Hobbie, 1984), but the lakes on Samoylov Island also experience stratification during summer, alternating with phases of complete mixing of the entire water body. In contrast, Duff et al. (1998) found that, in the Taimyr and Pechora River regions, the degree of stratification was mainly related to the water depth and the vegetation zone, and no stratification was observed in the tundra lakes (although this observation was based on individual measurements, rather than time series). The difference between surface and bottom temperatures in the tundra lakes 

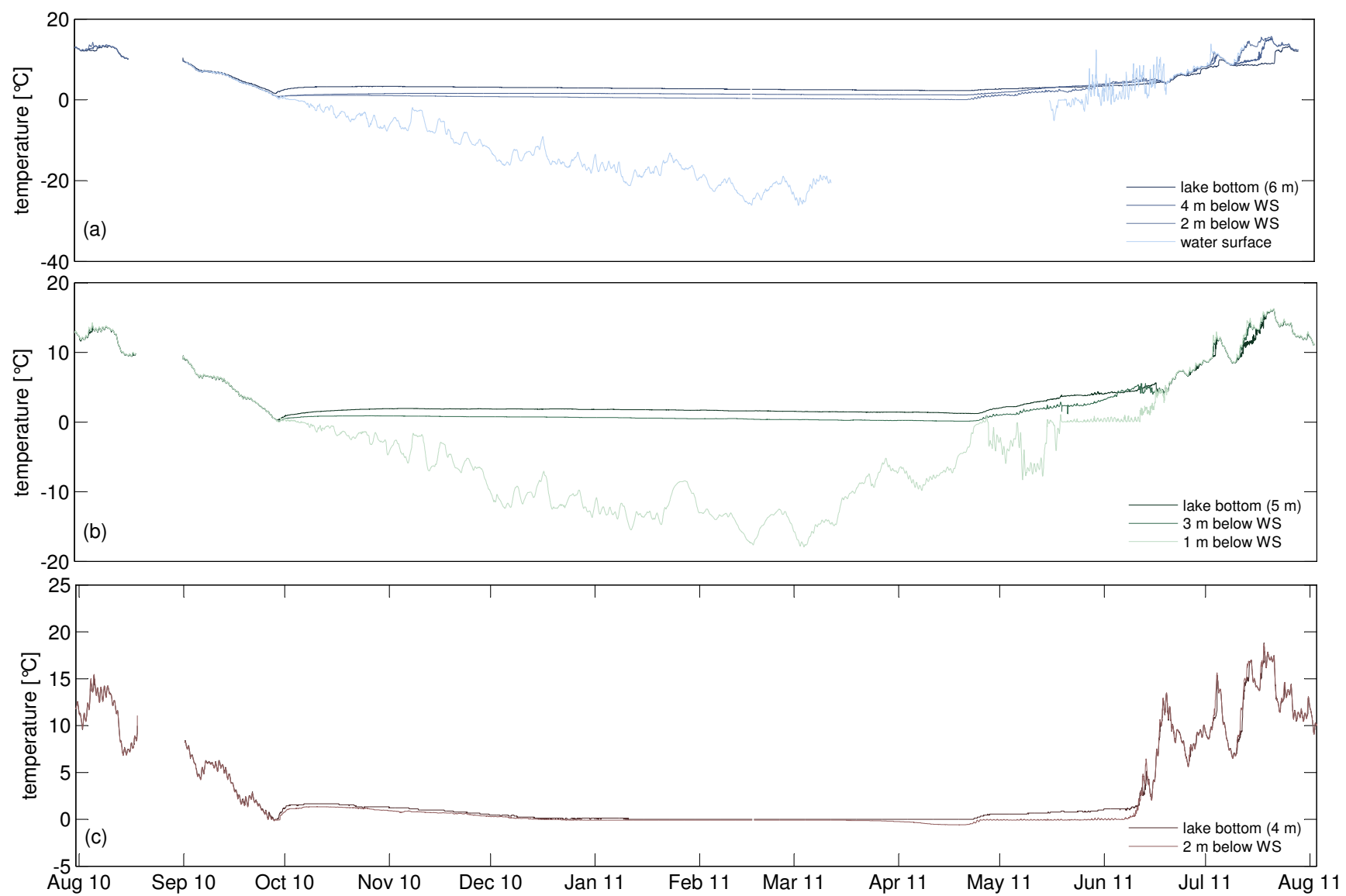

Fig. 14. Temperature dynamics in three thermokarst lakes for 2010-2011: (a) Lake 1, (b) Lake 2, and (c) Lake 3.

in the Taimyr and Pechora River regions was always $<2{ }^{\circ} \mathrm{C}$, even in two relatively deep $(>5 \mathrm{~m}$ ) lakes.

The long-term summer water budget calculated from precipitation minus evapotranspiration indicates a reasonably balanced situation on Samoylov Island with an average surplus of $5 \mathrm{~mm}$, but it is also characterised by high interannual variability. The summer water balance on the catchment scale was found to be mainly controlled by vertical fluxes (precipitation and evapotranspiration). On the other hand, pronounced redistribution of storage water due to lateral fluxes takes place within the microtopography of polygonal tundra (Liljedahl et al., 2012; Helbig et al., 2013). Averaged daily summer evaporation rates of $1.3 \mathrm{mmday}^{-1}$ are comparable to those for other sites in the Arctic. Evaporation rates are $1 \mathrm{~mm} \mathrm{day}^{-1}$ at Ny-Ålesund, Spitsbergen (Lloyd et al., 2001), $1.3 \mathrm{~mm} \mathrm{day}^{-1}$ in the Kevo area in northern Finland (Harding et al., 2002), $1.4 \mathrm{~mm} \mathrm{day}^{-1}$ in the Zackenberg valley, Greenland (Soegaard et al., 2001), and $1.5 \mathrm{~mm} \mathrm{day}^{-1}$ in Happy Valley, Alaska (Vourlitis and Oechel, 1999). Higher evaporation rates of $2.3 \mathrm{~mm} \mathrm{day}^{-1}$ were reported by Mendez et al. (1998) at Prudhoe Bay, Alaska. There are, in general, few published water balance studies available for low gradient polygonal landscapes (with pronounced microtopography and under- lain by permafrost) that also include lateral runoff measurements. A site with similar characteristics (Köppen-Geiger climate classification, summer evapotranspiration exceeds rainfall) and similar surfaces (wetland with ponds and lakes) for which water balance data are available is the Putuligayuk River watershed, located on the North Slope of Alaska, although it covers a much larger area $\left(471 \mathrm{~km}^{2}\right)$. The average summer runoff ratio for this site from 1999-2007 is 0.36, with a range from 0.1 to 0.64 (Kane et al., 2008). For the island of Samoylov the runoff ratio for 25 July to $20 \mathrm{Au}-$ gust 2008, was determined to be around 0.1 and, thus, at the lower end the values given by Kane et al. (2008).

The extent of the wetland and the way that it is likely to change with future variations in the climate depend mainly on the water balance, i.e., the difference between precipitation and evaporation (Boike et al., 2008; Woo et al., 2008). Thus, water bodies can serve as sentinels of environmental change (Smol et al., 2007) especially when remote-sensing observations are available.

There are few long-term water balance studies available for the Arctic. Hinzman et al. (2005) and Riordan et al. (2006) have presented estimates of long-term simplified $P$-ET water balances for Northern Alaska. Their 

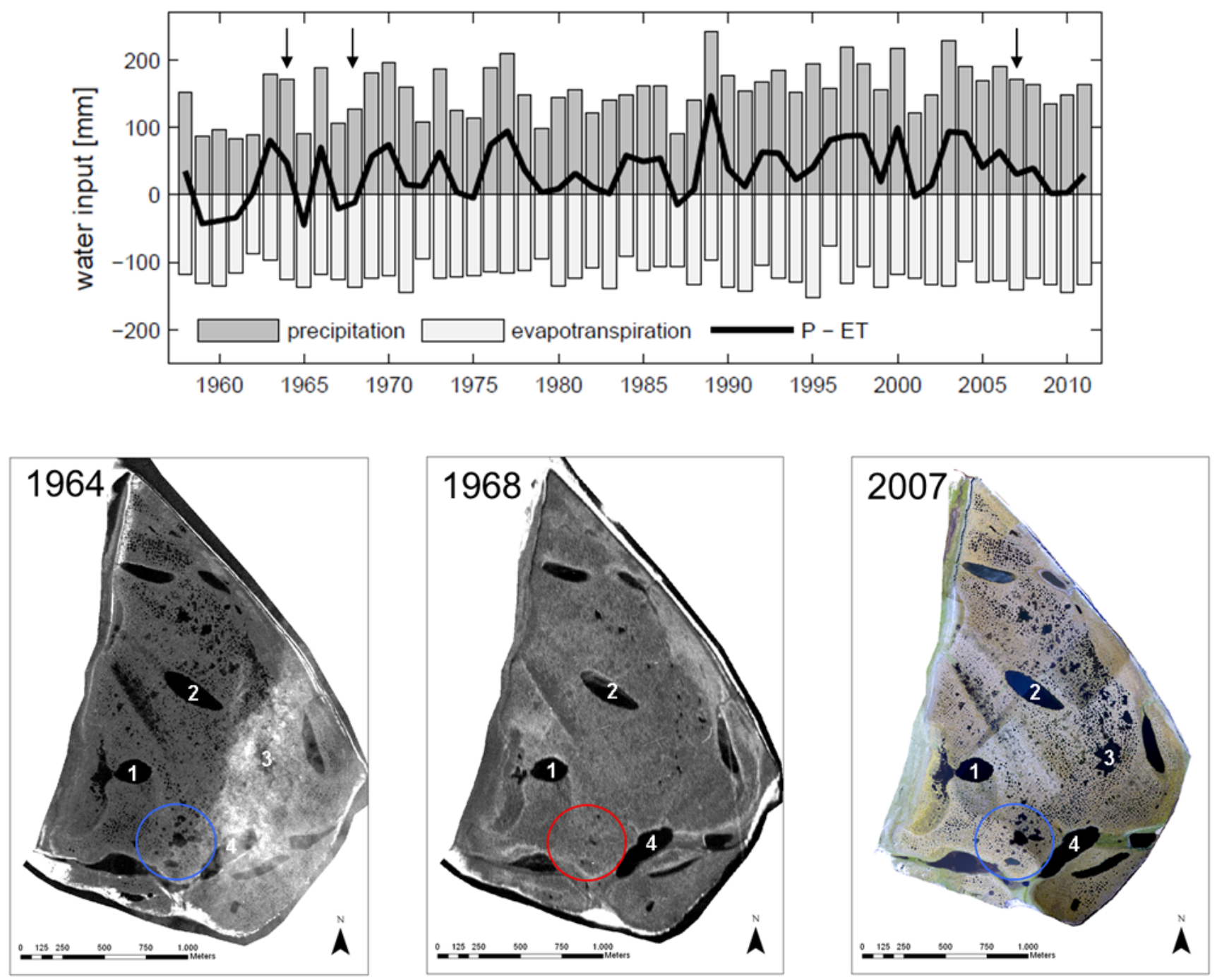

Fig. 15. Upper graph: annual long-term water budget calculations (precipitation- evapotranspiration, neglecting runoff) from 1958 to 2011. Air temperature ( $2 \mathrm{~m}$ above surface) and total precipitation data were obtained from ERA-40 and ERA-interim 6 hourly datasets. The ERA40 data are available on a Gaussian grid with a spatial resolution of $2.5^{\circ} \times 2.5^{\circ}$, while the resolution for ERA-interim data is slightly better at $1.5^{\circ} \times 1.5^{\circ}$. The data were interpolated between the four closest grid cells to the Samoylov Island site. The years for which high resolution CORONA data are available are marked with arrows. Lower images: CORONA high resolution (2.5 m) images of the Samoylov Island site (panchromatic KH-4A CORONA images from 17 August 1964 and 29 September 1968) and aerial mosaic from balloon aerial photography (August 2007). Lakes labelled 1 to 4 refer to the instrumented lakes discussed in Sect. 5.1. Note that ET on this figure is shown in negative numbers.

calculations of evaporation were based on the "uncorrected" Thornthwaite approach, i.e., they found significant reductions in the water balance despite no significant decrease in precipitation. These trends can be assumed to be an artifact caused by overestimations of evapotranspiration by the uncorrected Thornthwaite approach, as both derived annual evaporation totals that are 4 to 7 times higher than the measured evaporation rates reported from these regions (Rouse et al., 1992; Vourlitis and Oechel, 1999).

Both the current wetland extent and its controlling mechanisms have, to date, been only crudely simulated in earth system models (for example, using HadGEM2-ES). Model biases exist regarding regional and local surface water balances (Kattsov et al., 2007). Moreover, these models do not take into account subscale patterns and processes such as the spatiotemporal dynamics of low-centred ice-wedge polygons (de Klerk et al., 2011), or present-day land surface changes such as thermokarst lake formation (Jorgenson and Shur, 2007), increases in shrub cover (Sturm et al., 2001; Hinzman et al., 2005), prolongation of the snow-free season (Chapin et al., 2005), and changes in the surface water balance (Hinzman et al., 2005). 


\section{Summary and conclusions}

We have presented high resolution land surface properties that regulate surface radiation fluxes and the fluxes of heat and moisture. These characteristics are representative for the first terrace of the Lena River Delta and potentially for other Arctic river terraces with similar wetland polygonal tundra landscape. The characteristics are: (i) a fine scale variability with roughly half of the land surface dominated by wet surfaces; (ii) a large annual air temperature range of about $44{ }^{\circ} \mathrm{C}$; (iii) very cold annual permafrost temperatures of about $-8.6^{\circ} \mathrm{C}$ at $11 \mathrm{~m}$ depth; (iv) a high variability of annual end of snowmelt; (v) a high spatial and interannual variability of timing of complete freeze back of tundra and ponds, ranging from a month to several months; (vi) nonfrozen conditions below the ice cover of thermokarst lakes during winter; (vii) a roughly balanced water budget, i.e., precipitation balances evapotranspiration (runoff negligible).

No clear warming of air and active layer temperatures in the upper metre is detected since 1998, though winter air temperatures during recent years have not been as cold as in earlier years. The warming of permafrost of more than $1{ }^{\circ} \mathrm{C}$ at $10.7 \mathrm{~m}$ depth since 2006 is most likely related to changes in winter air temperature, radiation and snow cover. Because of its small areal coverage (around the margins of the North American and Eurasian land masses), this ecosystem faces potential extinction in a future changing climate. Located between the Arctic Ocean and the Siberian Continent, it also serves as a sentinel for changes within the Lena River catchment area. Finally, this site provides a unique opportunity for the study of small scale processes that are important for large-scale predictions (for example, small ponds have a large impact on the $\mathrm{CO}_{2}$ balance, Abnizova et al., 2012).

\section{Outlook: Samoylov Island - a new Arctic observatory}

The establishment of the Samoylov Island observatory, provides a unique opportunity to obtain coherent, reliable, longterm datasets for the polygonal tundra of Northern Siberia. Its aim is to focus, streamline and integrate the existing measurement campaigns and long-term monitoring programmes that have been conducted in the region over the past $15 \mathrm{yr}$. The Samoylov observatory will serve as a benchmark and validation site for earth system models, remote sensing and in situ change detection. In addition to the polygonal tundra landscape of Samoylov Island, the nearby islands (such as Kurungnah) feature different, homogeneous landscape units that are excellently suited for validation of multi-scale remote-sensing techniques. Permafrost monitoring based on remote sensing using multiple sensors (surface temperature, surface soil moisture, albedo, surface subsidence and snow cover properties), and numerical heat transfer modelling, have considerable potential when they can be related to field observations. Improvements in data collection would include the maintenance of high quality, year-round data on energy, water and carbon flux monitoring, with the data then being fed into international database. The collection of high resolution remote-sensing radar data (http://sss.terrasar-x.dlr.de/) to detect future changes over this area has already been initiated.

It is important to note that all modelling strategies require a field-based understanding of the surface characteristics and key processes involved, as well as monitoring data for a number of key parameters. The vision of a pan-Arctic state-ofthe-art network of "Arctic Observatories" in support of modelling efforts is, therefore, one that is well worth pursuing.

Acknowledgements. We would like to thank Waldemar Schneider for logistical support, Max Heikenfeld for data analysis, Paul Overduin for discussions, Soloviev Grigoriy for assistance with field work and Ed Manning for proofreading. This work was supported by the Helmholtz Association through a grant (VH-NG 203) awarded to Julia Boike and by the European Union FP7ENVIRONMENT project PAGE21 under contract no. GA282700.

Edited by: I. Bussmann

\section{References}

Abnizova, A., Siemens, J., Langer, M., and Boike, J.: Small ponds with major impact: the relevance of ponds and lakes in permafrost landscapes to carbon dioxide emissions, Global Biogeochem. Cy., 26, 2041, doi:10.1029/2011gb004237, 2012.

Abramov, I. I. and Volkova, L. A.: Handbook of Mosses of Karelia, KMK Scientific Press Delphos, Moscow, 390 pp., 1998.

ACIA: Impacts of a Warming Arctic: Arctic Climate Impacts Assessment, Cambridge, 1042, 2005.

AMAP: Snow, Water, Ice and Permafrost in the Arctic (SWIPA): Climate Change and the Cryosphere, Arctic Monitoring and Assessment Programme (AMAP), Oslo, Norway, xii + 538 pp. 2011.

Becker, H., Akhmadeeva, I., Wagner, D., Pfeiffer, E.-M., and Quass, W.: Soils of Samoylov Island, Reports on Polar and Marine Research, 315, 21-27, 1999.

Beringer, J., Chapin, F. S., Thompson, C. C., and McGuire, A. D.: Surface energy exchanges along a tundra-forest transition and feedbacks to climate, Agr. Forest Meteorol., 131, 143-161, 2005.

Blok, D., Heijmans, M., Schaepman Strub, G., Kononov, A. V., Maximov, T. C., and Berendse, F.: Shrub expansion may reduce summer permafrost thaw in Siberian tundra, Global Change Biol., 16, 1296-1305, doi:10.1111/j.1365-2486.2009.02110.x, 2010.

Boike, J., Hinzman, L. D., Overduin, P. P., Romanovsky, V., Ippisch, O., and Roth, K.: A Comparison of Snow Melt at Three Circumpolar Sites: Spitsbergen, Siberia, Alaska, 2003.

Boike, J., Wille, C., and Abnizova, A.: Climatology and summer energy and water balance of polygonal tundra in the Lena River Delta, Siberia, J. Geophys. Res., 113, 03025, doi:10.1029/2007JG000540, 2008. 
Boike, J., Langer, M., Lantuit, H., Muster, S., Roth, K., Sachs, T., Overduin, P., Westermann, S., and McGuire, A. D.: Permafrost physical aspects, carbon cycling, databases and uncertainties, in: Recarbonization of the Biosphere: Ecosystems and the Global Carbon Cycle, edited by: Lal, R., Springer Science + Business Media, 159-185, 2012.

Braun-Blanquet, J.: Pflanzensoziologie, 3rd Edn., Springer, Wien, 865 pp., 1964.

Brown, J. and Romanovsky, V. E.: Report from the International Permafrost Association: state of permafrost in the first decade of the 21st century, Permafrost Periglac., 19, 255-260, doi:10.1002/ppp.618, 2008.

Brown, J., Ferrians Jr., O. J., Heginbottom, J., and Melnikov, E.: Circum-Arctic map of permafrost and ground-ice conditions, National Snow and Ice Data Center/World Data Center for Glaciology, Boulder, CO, 1998.

CAVM Team 2003: Circumpolar Arctic Vegetation Map, 1: 7, 500, 000, US Fish and Wildlife Service, Anchorage, AK, 2003.

Chapin III, F., Sturm, M., Serreze, M., McFadden, J. P., Key, R. J., Lloyd, A. H., McGuire, A. D., Rupp, T. S., Lynch, A. H., Schimel, J. P., Beringer, J., Chapman, W. L., Epstein, H. E., Euskirchen, E. S., Hinzmann, L. D., Jia, G., Ping, C.-L., Tape, K. D., Thompson, C. D. C., Walker, D. A., and Welker, J. M.: Role of land-surface changes in Arctic summer warming, Science, 310, 657-660, 2005.

Cherepanov, S. K.: Vascular plants of Russia and adjacent states (the former USSR), Cambridge University Press, Cambridge, 516 pp., 1995.

Costard, F. and Gautier, E.: The Lena River: hydromorphodynamic features in a deep permafrost zone, in: Large Rivers - Geomorphology and Maganagement, edited by: Gupta, A., John Wiley and Sons, West Sussex, England, 225-233, 2007.

de Klerk, P., Donner, N., Karpov, N. S., Minke, M., and Joosten, H.: Short-term dynamics of a low-centred ice-wedge polygon near Chokurdakh (NE Yakutia, NE Siberia) and climate change during the last ca 1250 years, Quaternary Sci. Rev., 30, 3013-3031, doi:10.1016/j.quascirev.2011.06.016, 2011.

DIN 19683-1: Methods of soil analysis for water management for agricultural purposes - physical laboratory tests, Deutsches Institut für Normung e. V., Beuth Verlag, Berlin, 1973.

DIN 19684-1: Methods of soil analysis for water management for agricultural purposes - chemical laboratory tests - determination of the $\mathrm{pH}$ value of the soil and the lime requirement, Deutsches Institut für Normung e. V., Beuth Verlag, Berlin, 1977.

DIN ISO 10694: Soil quality - determination of organic and total carbon after dry combustion (elementary analysis), Deutsches Institut für Normung e. V., Beuth Verlag, Berlin, 1996.

Duff, K., Laing, T., Smol, J., and Lean, D. S.: Limnological characteristics of lakes located across arctic treeline in northern Russia, Hydrobiologia, 391, 203-220, doi:10.1023/a:1003542322519, 1998.

Eaton, A. K. and Rouse, W. R.: Controls on evapotranspiration at a subarctic sedge fen, Hydrol. Process., 15, 3423-3431, doi:10.1002/hyp.1029, 2001.

Eugster, W., Rouse, W. R., Pielke Sr., R. A., McFadden, J. P., Baldocchi, D. D., Kittel, T. G. F., Chapin III, F. S., Liston, G. E., Vidale, P. L., Vaganov, E., and Chambers, S.: Land-atmosphere energy exchange in Arctic tundra and boreal forest: available data and feedbacks to climate, Global Change Biol., 6, 84-115, 2000.
Fedorova, I., Chetverova, A., Bolshiyanov, D., Makarov, A, Boike, J., Wegner, K., Heim, B., and Kashina, V.: Hydrological and geochemical investigation of the Lena Delta during RussianGerman collaboration, in preparation, 2012.

Fiedler, S., Wagner, D., Kutzbach, L., and Pfeiffer, E.-M.: Element redistribution along hydraulic and redox gradients of lowcentered-polygons, Lena Delta, Northern Siberia, Soil Sci. Soc. Am. J., 68, 1002-1011, 2004.

Frahm, J. P. and Frey, W.: Moosflora, Ulmer, Stuttgart, 528 pp., 1992.

Gersper, P. L., Alexander, V., Barkley, L. A., Barsdate, R. J., and Flint, P. S.: The soils and their nutrients, in: An Arctic Ecosystem: the Coastal tundra at Barrow, edited by: Brown, J., Miller, P. C., Tieszen, L. L., and Bunnell, F. L., Alaska, Dowden, Hutchinson and Ross, Inc. Stroudsburg, PA, 219-254, available at: http://www.geobotany.org/library/pubs/GersperPL1980_ arcecosys_ch7.pdf, (last access: August 2012), 1980.

Grigoriev, M.: Cryomorphogenesis in the Lena Delta (in Russian). Permafrost Institute Press, Yakutsk, 176 pp., 1993.

Harding, R. J., Jackson, N. A., Blyth, E. M., and Culf, A.: Evaporation and energy balance of a sub-arctic hillslope in Northern Finland, Hydrol. Process., 16, 1419-1436, 2002.

Helbig, M., Boike, J., Langer, M., Schreiber, P., Runkle, B. R. K., Kutzbach, L.: Spatial and seasonal variability of polygonal tundra water balance, Lena River Delta, northern Siberia, Hydrogeol. J., 21, 133-147, doi:10.1007/s10040-012-0933-4, 2013.

Hinkel, K. M., Paetzold, F., Nelson, F. E., and Bockheim, J. G.: Patterns of soil temperature and moisture in the active layer and upper permafrost at Barrow, Alaska: 1993-1999, Global Planet. Change, 29, 293-309, 2001.

Hinzman, L. D., Bettez, N. D., Bolton, W. R., Chapin, F. S., Dyurgerov, M. B., Fastie, C. L., Griffith, B., Hollister, R. D., Hope, A., Huntington, H. P., Jensen, A. M., Jia, G. J., Jorgenson, T., Kane, D. L., Klein, D. R., Kofinas, G., Lynch, A. H., Lloyd, A. H., McGuire, A. D., Nelson, F. E., Oechel, W. C., Osterkamp, T. E., Racine, C. H., Romanovsky, V. E., Stone, R. S., Stow, D. A., Sturm, M., Tweedie, C. E., Vourlitis, G. L., Walker, M. D., Walker, D. A., Webber, P. J., Welker, J. M., Winker, K. S., and Yoshikawa, K.: "Evidence and Implications of Recent Climate Change in Northern Alaska and Other Arctic Regions", Climatic Change, 72, 251-298, 2005.

Hobbie, J. E.: Polar limnology, in: Lakes and Reservoirs, edited by: Taub, F. B., Elsevier, Amsterdam, 63-105, 1984.

Jorgenson, M. T. and Shur, Y.: Evolution of lakes and basins in northern Alaska and discussion of the thaw lake cycle, J. Geophys. Res., 112, F02S17, doi:10.1029/2006jf000531, 2007.

Kane, D. L, Gieck, R., and Boudreau, L.: Water balance for a low gradient watershed in northern Alaska, in: Proceedings of the Ninth International Conference on Permafrost, edited by: Kane, D. L. and Hinkel, K. M., University of Alaska, Institute of Northern Engineering, Fairbanks, AK, 883-888, 2008.

Kattsov, V., Walsh, J., Chapman, W., Govorkova, V., Pavlova, T., and Zhang, X.: Simulation and projection of Arctic freshwater budget components by the IPCC AR4 global climate models, J. Hydrometerol., 8, 571-589, 2007.

Knoblauch, C., Zimmermann, U., Blumenberg, M., Michaelis, W., and Pfeiffer, E.-M.: Methane turnover and temperature response of methane-oxidizing bacteria in permafrost-affected soils of northeast Siberia, Soil Biol. Biochem., 40, 3004-3013, 
doi:10.1016/j.soilbio.2008.08.020, 2008.

Kutzbach, L.: The exchange of energy, water and carbon dioxide between wet Arctic tundra and the Atmosphere at the Lena River Delta, Northern Siberia, reports on polar and marine research 541, Ph. D. thesis, Alfred Wegener Institute, University of Hamburg, Bremerhaven, Germany, 157 pp., 2006.

Kutzbach, L., Wagner, D., and Pfeiffer, E. M.: Effect of microrelief and vegetation on methane emission from wet polygonal tundra, Lena Delta, Northern Siberia, Biogeochemistry, 69, 341-362, 2004.

Kutzbach, L., Wille, C., and Pfeiffer, E.-M.: The exchange of carbon dioxide between wet arctic tundra and the atmosphere at the Lena River Delta, Northern Siberia, Biogeosciences, 4, 869-890, doi:10.5194/bg-4-869-2007, 2007.

Lachenbruch, A. H.: Mechanics of Thermal Contraction Cracks and Ice-Wedge Polygons in Permafrost, Special gsa papers, New York, 1962.

Lachenbruch, A. H.: Contraction Theory of Ice Wedge Polygons: a Quantitative Discussion, Permafrost International Conference, Purdue Univeristy Lafayette, Indiana, 1963, 563, 1966.

Langer, M., Westermann, S., and Boike, J.: Spatial and temporal variations of summer surface temperatures of wet polygonal tundra in Siberia - implications for modis 1st based permafrost monitoring, Remote Sens. Environ., 114, 2059-2069, doi:10.1016/j.rse.2010.04.012 2010.

Langer, M., Westermann, S., Muster, S., Piel, K., and Boike, J.: The surface energy balance of a polygonal tundra site in northern Siberia - Part 1: Spring to fall, The Cryosphere, 5, 151-171, doi:10.5194/tc-5-151-2011, 2011a.

Langer, M., Westermann, S., Muster, S., Piel, K., and Boike, J.: The surface energy balance of a polygonal tundra site in northern Siberia - Part 2: Winter, The Cryosphere, 5, 509-524, doi:10.5194/tc-5-509-2011, 2011b.

Legendre, P.: Program K-means user's guide, 2001.

Legendre, P. and Gallagher, C. J.: Ecologically meaningful transformations for ordination of species data, Oecologia, 129, 271-280, doi:10.1007/s004420100716, 2001.

Liebner, S., Zeyer, J., Wagner, D., Schubert, C., Pfeiffer, E. M., and Knoblauch, C.: Methane oxidation associated with submerged brown mosses reduces methane emissions from Siberian polygonal tundra, J. Ecol., 99, 914-922, doi:10.1111/j.13652745.2011.01823.x, 2011.

Liljedahl, A. K., Hinzman, L. D., Harazono, Y., Zona, D., Tweedie, C. E., Hollister, R. D., Engstrom, R., and Oechel, W. C.: Nonlinear controls on evapotranspiration in arctic coastal wetlands, Biogeosciences, 8, 3375-3389, doi:10.5194/bg-8-33752011, 2011.

Liljedahl, A. K, Hinzman, L. D, and Schulla, J.: Ice-wedge polygon type controls low-gradient watershed scale hydrology, in: Proceedings of the Tenth International Conference on Permafrost, vol 1: International contributions, edited by: Hinkel, K. M., The Northern Publisher, Salehard, Russia, 231-236, 2012.

Lloyd, C. R., Harding, R. J., Friborg, T., and Aurela, M.: Surface fluxes of heat and water vapour from sites in the European Arctic, Theor. Appl. Climatol., 70, 19-33, 2001.

Lynch, A. H., Chapin III, F. S., Hinzman, L. D., Wu, W., Lilly, E., Vourlitis, G., and Kim, E.: Surface energy balance on the Arctic tundra: measurements and models, J. Climate, 12, 2585-2606, 1999.
Mackay, J. R.: The world of underground ice, Ann. Assoc. Am. Geogr., 62, 1-22, 1972.

Mackay, J. R.: Thermally induced movements in ice-wedge polygons, Western Arctic coast: a long-term study, Géogr. Phys. Quatern., 54, 41-68, 2000.

Mackay, J. R. and Burn, C. R.: The first 20 yr (1978-1979 to 19981999) of ice-wedge growth at the Illisarvik experimental drained lake site, Western Arctic coast, Canada, Can. J. Earth Sci., 39, 95-111, 2002.

Mendez, J., Hinzman, L. D., and Kane, D. L.:Evapotranspiration from a wetland complex on the arctic coastal plain of Alaska, Nord. Hydrol., 29, 303-330, 1998.

Minke, M., Donner, N., Karpov, N. S., de Klerk, P., and Joosten, H.: Distribution, diversity, development and dynamics of polygon mires: examples from Northeast Yakutia (Sibiria), Peatlands International, 1, 36-40, 2007.

Minke, M., Donner, N., Karpov, N., Klerk, P. d., and Joosten, H.: Patterns in vegetation composition, surface height and thaw depth in polygon mires in the Yakutian Arctic (NE Siberia): a microtopographical characterisation of the active layer, Permafrost Periglac., 20, 357-368, 2009.

Muster, S., Langer, M., Heim, B., Westermann, S., and Boike, J.: Subpixel heterogeneity of ice-wedge polygonal tundra: a multi-scale analysis of land cover and evapotranspiration in the Lena River Delta, Siberia, Tellus B, 64, 17301, doi:10.3402/tellusb.v64i0.17301, 2012.

Muster, S., Heim, B., Abnizova, A., and Boike, J.: Water Body Distributions Across Scales: A Remote Sensing Based Comparison of Three Arctic Tundra Wetlands, Remote Sensing, 5, 14981523, doi:10.3390/rs5041498, 2013.

NASA Landsat Programme: Lena Delta in Landsat 7/ETM+, Visible Earth, v1 ID: 407 18024, 2000, available at: http:// visibleearth.nasa.gov/, (last access: 10 October 2011), 2000.

Naumov Ye, M.: Soils and soil cover of Northeastern Eurasia, in: Cryosols, edited by: Kimble, J. M., Springer, Heidelberg, 161$183,2004$.

Oberman, N. G.: Contemporary permafrost degradation of Northern European Russia, 9th International Conference on Permafrost, Institute of Northern Engineering, Fairbanks, Alaska, 2008.

Osterkamp, T. E.: Thermal state of permafrost in Alaska during the fourth quarter of the twentieth century, 9th International Conference on Permafrost, Institute of Northern Engineering, Fairbanks, Alaska, 2008.

Peel, M. C., Finlayson, B. L., and McMahon, T. A.: Updated world map of the Köppen-Geiger climate classification, Hydrol. Earth Syst. Sci., 11, 1633-1644, doi:10.5194/hess-11-16332007, 2007.

Ping, C. L., Clark, M. H., and Swanson, D. K.: Chapter 2, in: Cryosols in Alaska, 71-94, 2004.

Rawlins, M. A., Serreze, M. C., Schroeder, R., Zhang, X., and McDonald, K. C.: Diagnosis of the record discharge of Arcticdraining Eurasian rivers in 2007, Environ. Res. Lett., 4, 1-8, 2009a.

Rawlins, M. A., Steele, M. A., Serreze, M. C., Vörösmarty, C. J., Ermold, W., Lammers, R. B., McDonald, K. C., Pavelsky, T. M., Shiklomanov, A., and Zhang, J.: Tracing freshwater anomalies through the air-land-ocean system: a case study from the Mackenzie River Basin and the Beaufort Gyre, Atmos. Ocean, 47, 79-97, 2009b. 
Riordan, B., Verbyla, D., and McGuire, A. D.: Shrinking ponds in subarctic Alaska based on 1950-2002 remotely sensed images, J. Geophys. Res., 111, G04002, doi:10.1029/2005JG000150, 2006.

Romanovsky, V. E., Sazonova, T. S., Balobaev, V. T., Shender, N. I., and Sergueev, D. O.: Past and recent changes in air and permafrost temperatures in Eastern Siberia, Global Planet. Change, 56, 399-413, doi:10.1016/j.gloplacha.2006.07.022, 2007.

Romanovsky, V. E., Drozdov, D. S., Oberman, N. G., Malkova, G. V., Kholodov, A. L., Marchenko, S. S., Moskalenko, N. G., Sergeev, D. O., Ukraintseva, N. G., and Abramov, A. A.: Thermal state of permafrost in Russia, Permafrost Periglac., 21, 136-155, doi:10.1002/ppp.683, 2010a.

Romanovsky, V. E., Smith, S. L., and Christiansen, H. H.: Permafrost thermal state in the polar Northern Hemisphere during the international polar year 2007-2009: a synthesis, Permafrost Periglac., 21, 106-116, doi:10.1002/ppp.689, 2010 b.

Rouse, W. R., Carlson, D. W., and Weick, J.: Impacts of summer warming on the energy and water balance of Wetland tundra, Climatic Change, 22, 305-326, 1992.

Runkle, B. R. K., Sachs, T., Wille, C., Pfeiffer, E.-M., and Kutzbach, L.: Bulk partitioning the growing season net ecosystem exchange of $\mathrm{CO}_{2}$ in Siberian tundra reveals the seasonality of its carbon sequestration strength, Biogeosciences, 10, 1337-1349, doi:10.5194/bg-10-1337-2013, 2013.

Sachs, T., Wille, C., Boike, J., and Kutzbach, L.: Environmental controls on ecosystem-scale $\mathrm{CH}_{4}$ emission from polygonal tundra in the Lena River Delta, Siberia, J. Geophys. Res., 113, G00A03, doi:10.1029/2007JG000505, 2008.

Sachs, T., Giebels, M., Boike, J., and Kutzbach, L.: Environmental controls on $\mathrm{CH}_{4}$ emission from polygonal tundra on the microsite scale in the Lena River Delta, Siberia, Global Change Biol., 16, 3096-3110, doi:10.1111/j.1365-2486.2010.02232.x, 2010.

Sanders, T., Fiencke, C., and Pfeiffer, E.-M.: Small-scale variability of dissolved inorganic nitrogen (DIN), $\mathrm{C} / \mathrm{N}$ ratios and ammonia oxidizing capacities in various permafrost affected soils of Samoylov Island, Lena River Delta, Northeast Siberia, Polarforschung, 80, 23-35, 2010.

Scheritz, M., Dietrich, R., Scheller, S., Schneider, W., and Boike, J.: Digital elevation model of polygonal patterned ground on Samoylov Island, Siberia, using small-format aerial photography, 9th International Conference on Permafrost, Fairbanks, Alaska, 2008, 1589-1594, 2008.

Schneider, J., Grosse, G., and Wagner, D.: Land cover classification of tundra environments in the Arctic Lena Delta based on Landsat 7 ETM+ data and its application for upscaling of methane emissions, Remote Sens. Environ., 113, 380-391, doi:10.1016/j.rse.2008.10.013, 2009.

Smith, S. L., Romanovsky, V. E., Lewkowicz, A. G., Burn, C. R., Allard, M., Clow, G. D., Yoshikawa, K., and Throop, J.: Thermal state of permafrost in North America: a contribution to the international Polar year, Permafrost Periglac., 21, 117-135, doi:10.1002/ppp.690, 2010.

Smol, J. P. and Douglas, M. S. V.: Crossing the final ecological threshold in high Arctic ponds, P. Natl. Acad. Sci. USA, 104, 12395-12397, doi:10.1073/pnas.0702777104, 2007.

Soegaard, H., Hasholt, B., Friborg, T., and Nordstroem, C.: Surface Energy- and Water Balance in a high-Arctic environment in NE Greenland, Theor. Appl. Climatol., 70, 35-51, 2001.
Soil Survey Staff: Keys to Soil Taxonomy, 11th Edn., USDANatural Resources Conservation Service, Washington, DC, 2010.

Sturm, M., Racine, C., and Tape, K.: Climate change: increasing shrub abundance in the Arctic, Nature, 411, 546-547, 2001.

Tarnocai, C. and Zoltai, S. C.: Wetlands of Arctic Canada, in: Wetlands of Canada, edited by: National Wetlands Working Group, Polyscience Publications Inc., Montreal, 27-54, 1988.

Tarnocai, C., Canadell, J. G., Schuur, E. A. G., Kuhry, P., Mazhitova, G., and Zimov, S.: Soil organic carbon pools in the northern circumpolar permafrost region, Global Biogeochem. Cy., 23, 2023, doi:10.1029/2008GB003327, 2009.

Thornthwaite, C. W.: An approach toward a rational classification of climate, Geogr. Rev., 38, 55-94, 1948.

Vourlitis, G. L. and Oechel, W. C.: Eddy covariance measurements of $\mathrm{CO}_{2}$ and energy fluxes of an Alaskan tussock tundra ecosystem, Ecology, 80, 686-701, 1999.

Wagner, D., Gattinger, A., Embacher, A., Pfeiffer, E.-M., Schloter, M., and Lipski, A.: Methanogenic activity and biomass in holocene permafrost deposits of the Lena Delta, Siberian Arctic and its implication for the global methane budget, Global Change Biol., 13, 1089-1099, doi:10.1111/j.13652486.2007.01331.x, 2007.

Walker, D. A., Raynolds, M. K., Daniëls, F. J. A., Einarsson, E., Elvebakk, A., Gould, W. A., Katenin, A. E., Kholod, S. S., Markon, C. J., Melnikov, E. S., Moskalenko, N. G., Talbot, S. S., Yurtsev, B. A., and the other members of the CAVM Team: The circumpolar Arctic vegetation map, J. Veg. Sci., 16, 267282, 2005.

Washburn, A. L.: Geocryology: a Survey of Periglacial Processes and Environments, Arnold, London, 1979.

Webber, P. J.: Spatial and temporal variation in the vegetation and its productivity, Barrow, Alaska, in: Vegetation and Production Ecology of an Alaskan Arctic tundra, edited by: Tieszen, L. L., Springer-Verlag, New York, 37-112, 1978.

Webber, P. J. and Walker, D. A.: Vegetation and landscape analysis at Prudhoe Bay, Alaska: a vegetation map of the tundra biome study area, in: Ecological Investigations of the Tundra Biome in the Prudhoe Bay Region, edited by: Brown, J., Alaska, University of Alaska Fairbanks, Fairbanks, A. K., 81-91, 1975.

Webber, P. J., Miller, P. C., Chapin III, F. S., and McCown, B. H.: The vegetation: pattern and succession. in: An Arctic Ecosystem: the Coastal tundra at Barrow, edited by: Brown, J., Miller, P. C., Tieszen, L. L., and Bunnell, F. L., Alaska, Dowden, Hutchinson and Ross, Stroudsburg, PA., 186-218, 1980.

Westermann, S., Lüers, J., Langer, M., Piel, K., and Boike, J.: The annual surface energy budget of a high-arctic permafrost site on Svalbard, Norway, The Cryosphere, 3, 245-263, doi:10.5194/tc3-245-2009, 2009.

Wetterich, S., Schirrmeister, L., Meyer, H., Andreas, F. A., and Mackensen, A.: Arctic freshwater ostracods from modern periglacial environments in the Lena River Delta (Siberian Arctic, Russia): geochemical applications for palaeoenvironmental reconstructions, J. Paleolimnol., 39, 363-376, doi:10.1007/s10933-005-5801-y, 2008.

Wille, C., Kutzbach, L., Sachs, T., Wagner, D., and Pfeiffer, E.-M.: Methane emission from Siberian arctic polygonal tundra: eddy covariance measurements and modelling, Global Change Biol., 14, 1395-1408, doi:10.1111/j.1365-2486.2008.01586.x, 2008. 
Wirth, V.: Flechtenflora: Bestimmung und ökologische Kennzeichnung der Flechten Südwestdeutschlands und angrenzender Gebiete, Ulmer, Stuttgart, 661 pp., 1995.

Woo, M.-K., Kane, D., Carey, S., and Yang, D.: Progress in permafrost hydrology in the new millenium, Permafrost Periglac., 19, 237-254, 2008.

Yershov, E. D., Kondrat'yeva, K. A., Loginov, V. F., and Sychev, I. K.: Geocryological Map of Russia and Neighbouring Republics, Faculty of Geology, Chair of Geocryology, Lomonosov Moscow State University, 1991.

Zhang, Y., Sachs, T., Li, C., and Boike, J.: Upscaling methane fluxes from closed chambers to eddy covariance based on a permafrost biogeochemistry integrated model, Global Change Biol., 18, 1428-1440, doi:10.1111/j.1365-2486.2011.02587.x, 2012.
Zubrzycki, S., Kutzbach, L., and Pfeiffer, E.-M.: Böden in Permafrostgebieten der Arktis als Kohlenstoffsenke und Kohlenstoffquelle (Soils in arctic permafrost regions as carbon sink and source), Polarforschung, 81, 33-46, 2012a.

Zubrzycki, S., Kutzbach, L., Grosse, G., Desyatkin, A., and Pfeiffer, E.-M.: Organic carbon and total nitrogen stocks in soils of the Lena River Delta, Biogeosciences Discuss., 9, 17263-17311, doi:10.5194/bgd-9-17263-2012, 2012 b. 